\title{
1 Integrated view and comparative analysis of baseline protein 2 expression in mouse and rat tissues
}

3

4

5

6

\section{Shengbo Wang ${ }^{1 \dagger}$, David García-Seisdedos ${ }^{1,2 \uparrow}$, Ananth Prakash ${ }^{1,2 \dagger^{*}}$, Deepti Jaiswal Kundu ${ }^{1}$,} Andrew Collins ${ }^{3}$, Nancy George ${ }^{1}$, Silvie Fexova ${ }^{1}$, Pablo Moreno ${ }^{1}$, Irene Papatheodorou ${ }^{1,2}$, Andrew R. Jones ${ }^{3}$, Juan Antonio Vizcaíno ${ }^{1,2}$ *

${ }^{1}$ European Molecular Biology Laboratory - European Bioinformatics Institute (EMBL-EBI), Wellcome Genome Campus, Hinxton, Cambridge, CB10 1SD. United Kingdom.

${ }^{2}$ Open Targets, Wellcome Genome Campus, Hinxton, Cambridge, CB10 1SD. United Kingdom.

${ }^{3}$ Institute of Systems, Molecular and Integrative Biology, University of Liverpool, Liverpool L69 7ZB, United Kingdom.

*Corresponding authors.

$\dagger$ All three authors have contributed equally and they wish to be considered as joint first authors.

Dr. Ananth Prakash. European Molecular Biology Laboratory, European Bioinformatics Institute (EMBL-EBI), Wellcome Trust Genome Campus, Hinxton, Cambridge, CB10 1SD, UK. Phone: + 44 (0) 1223 492610. Email: ananth@ebi.ac.uk

Dr. Juan Antonio Vizcaíno. European Molecular Biology Laboratory, European Bioinformatics Institute (EMBL-EBI), Wellcome Trust Genome Campus, Hinxton, Cambridge, CB10 1SD, UK. Phone: + 44 (0) 1223 492686. Email: juan@ebi.ac.uk. 
bioRxiv preprint doi: https://doi.org/10.1101/2021.12.20.473413; this version posted December $21,2021$. The copyright holder for this preprint (which was not certified by peer review) is the author/funder, who has granted bioRxiv a license to display the preprint in perpetuity. It is made available under aCC-BY-NC-ND 4.0 International license.

\section{Keywords}

34 Mass spectrometry, quantitative proteomics, comparative protein expression, public data re-

35 use, rat proteome, mouse proteome, PRIDE 


\section{Abstract}

37 The increasingly large amount of public proteomics data enables, among other applications,

38 the combined analyses of datasets to create comparative protein expression maps covering

39 different organisms and different biological conditions. Here we have reanalysed public

40 proteomics datasets from mouse and rat tissues (14 and 9 datasets, respectively), to assess

41 baseline protein abundance. Overall, the aggregated dataset contains 23 individual datasets,

42 which have a total of 211 samples coming from 34 different tissues across 14 organs,

43 comprising 9 mouse and 3 rat strains, respectively.

45 We compared protein expression between the different organs, including the distribution of

46 proteins across them. We also performed gene ontology and pathway enrichment analyses to

47 identify organ-specific enriched biological processes and pathways. As a key point we carried

48 out a comparative analysis of protein expression between mouse, rat and human tissues. We

49 observed a high level of correlation of protein expression among orthologs between all three

50 species in brain, kidney, heart and liver samples. Finally, it should be noted that protein

51 expression results have been integrated into the resource Expression Atlas for widespread

52 dissemination. 


\section{Author summary}

56 We have reanalysed 23 baseline public proteomics datasets stored in the PRIDE database

57 belonging to various mouse and rat tissues and organs. Overall, the aggregated dataset

58 contained 211 samples, coming from 34 different tissues across 14 organs, comprising 9

59 mouse and 3 rat strains, respectively. We analysed the distribution of protein expression

60 across organs in both species. Then we performed gene ontology and pathway enrichment

61 analyses to identify organ-specific enriched biological processes and pathways. We also

62 carried out a comparative analysis of baseline protein expression between mouse, rat and

63 human tissues, observing a high level of expression correlation among orthologs in all three

64 species, in brain, kidney, heart and liver samples. To disseminate these findings, we have integrated the protein expression results into the resource Expression Atlas. 


\section{Introduction}

High-throughput mass spectrometry (MS)-based proteomics approaches have matured significantly in recent years, becoming an essential tool in biological research [1]. This has been the consequence of very significant technical improvements in MS instrumentation, chromatography, automation in sample preparation and computational analyses, among other areas. The most used MS-based experimental approach is Data Dependent Acquisition (DDA) bottom-up proteomics. Among the main quantitative proteomics DDA techniques, label-free approaches remain very popular, although labelled-approaches, especially those techniques based on the isotopic labelling of peptides (MS ${ }^{2}$ labelling), such as iTRAQ (Isobaric tag for relative and absolute quantitation) and TMT (Tandem Mass Tagging), are increasingly popular as well.

Following the steps initiated by genomics and transcriptomics, open data practices in the field have become embedded and commonplace in proteomics in recent years. In this context, datasets are now commonly available in the public domain to support the claims published in the corresponding manuscripts. The PRIDE database [2], located at the European Bioinformatics Institute (EBI), is currently the largest resource worldwide for public proteomics data deposition. PRIDE is also one of the founding members of the global ProteomeXchange consortium [3], involving five other resources, namely PeptideAtlas, MassIVE, iProX, jPOST and PanoramaPublic. ProteomeXchange has standardised data submission and dissemination of public proteomics data worldwide.

As a consequence, there is an unprecedented availability of data in the public domain, which is triggering multiple applications [4], including the joint reanalysis of datasets (so-called 
91 meta-analysis studies) [5-7]. Indeed, public proteomics datasets can be systematically reanalysed and integrated e.g., to confirm the results reported in the original publications, potentially in a more robust manner since evidence can be strengthened if it is found consistently across different datasets. Potentially, new insights different to the aims of the original studies can also be obtained by re-analysing the datasets using different strategies. It is the so-called re-purposing of public datasets [8], including for instance proteogenomics studies, for genome annotation purposes [9-12].

In this context of reuse of public proteomics data, PRIDE has started to work on developing

100 data dissemination and integration pipelines into popular added-value resources at the EBI.

101 This is perceived as a more sustainable approach in the medium-long term than setting up new bioinformatics resources. One of them is Expression Atlas [13], a resource that has enabled over the years easy access to gene expression data across species, tissues, cells,

104 experimental conditions and diseases. Only recently, protein expression information coming 105 from reanalysed datasets has been integrated in the 'bulk' section of Expression Atlas. As a result, proteomics expression data can be integrated with transcriptomics information, mostly coming from RNA-Seq experiments. So far, we have performed two main meta-analysis studies involving the reanalysis and integration of: (i) 11 public quantitative datasets coming

109 from cell lines and human tumour samples [14]; and (ii) 25 human baseline datasets coming 110 from 32 different organs [15].

112 The next logical step is to perform an analogous study of baseline protein expression in two

113 of the main model organisms: Mus musculus and Rattus norvegicus. To date, there are only a

114 small number of bioinformatics resources providing access to reanalysed MS-based

115 quantitative proteomics datasets, and even fewer if one considers only mouse and rat data. In 
116 this context, at the end of 2020, ProteomicsDB [16] released a first version of the mouse

117 proteome, based on the re-analysis of five datasets. To the best of our knowledge, there is no

118 such public resource for rat data yet anywhere. Additionally, although antibody-based human

119 protein expression information is provided via the Human Protein Atlas [17], their efforts are

120 focused on human protein expression. Here, we report the reanalysis and integration of 23

121 public mouse (14 datasets) and rat (9 datasets) label-free datasets, and the incorporation of

122 the results into the resource Expression Atlas as baseline studies. Additionally, we report a

123 comparative analysis of protein expression across mouse, rat and human (in this case using

124 the results reported at [15] using the same methodology). 


\section{Result}

\subsection{Baseline proteomics datasets}

129 Overall, we quantified protein expression from 34 healthy tissues in 14 organs coming from

13023 datasets. The analyses covered a total of 1,173 MS runs from 211 samples that were

131 annotated as healthy/control/non-treated samples thus representing baseline protein expression. Non-control/disease samples associated with these datasets were also analysed

133 but are not discussed here. Normalised protein abundances values (as ppb, parts per billion)

134 from both control/healthy/non-treated and disease/treated tissue samples are available to view

135 as heatmaps in Expression Atlas. The protein abundances along with sample annotations, sample quality assessment summary and experimental parameter inputs for MaxQuant can be downloaded from Expression Atlas as text files. Data selection and reanalysis protocol is shown in Table 1.

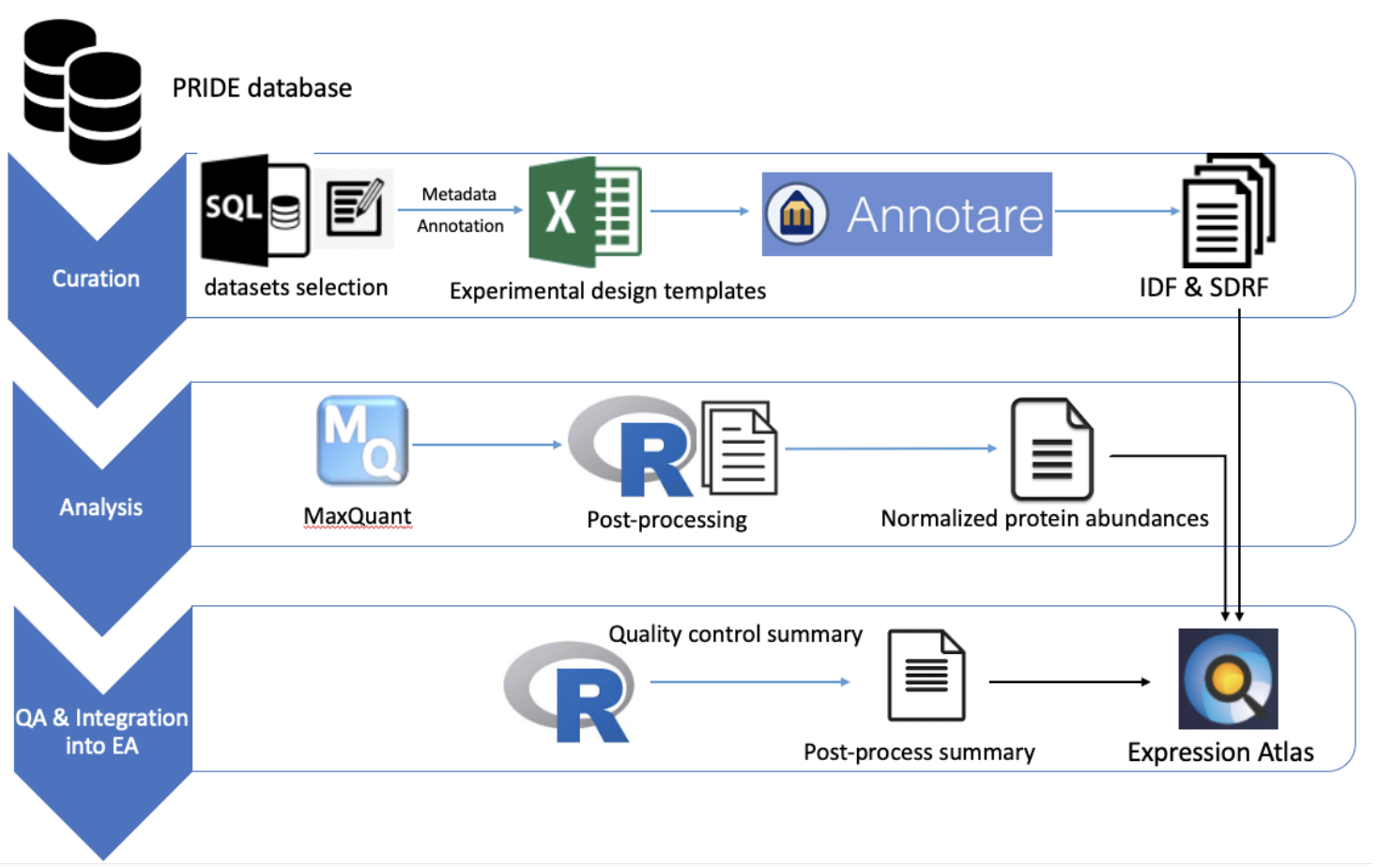

141 Figure 1. An overview of the study design and reanalysis pipeline. QA: Quality assessment. 


\begin{tabular}{|c|c|c|c|c|c|c|c|c|c|c|c|}
\hline $\begin{array}{l}\text { Expression } \\
\text { Atlas } \\
\text { accession } \\
\text { numbers } \\
\end{array}$ & $\begin{array}{l}\text { PRIDE dataset } \\
\text { identifiers }\end{array}$ & Tissues & Organs & Species & Strain & $\begin{array}{l}\text { Number of } \\
\text { MS runs }\end{array}$ & $\begin{array}{l}\text { Number of } \\
\text { samples }\end{array}$ & $\begin{array}{l}\text { Number of } \\
\text { protein } \\
\text { groups }^{\dagger}\end{array}$ & $\begin{array}{l}\text { Number } \\
\text { of } \\
\text { peptides } \\
+\end{array}$ & $\begin{array}{l}\text { Number of } \\
\text { unique } \\
\text { peptides }^{\dagger}\end{array}$ & $\begin{array}{l}\begin{array}{l}\text { Number of } \\
\text { unique } \\
\text { genes } \\
\text { mapped }^{\dagger}\end{array} \\
\end{array}$ \\
\hline E-PROT-7 ${ }^{\S}$ & PXD000867 ${ }^{[18]}$ & Liver & Liver & Mus musculus & $\mathrm{C} 57 \mathrm{BL} / 6 \mathrm{~J}$ & 24 & 4 & 12,792 & 246,738 & 167,725 & 9,715 \\
\hline E-PROT- $10^{\S}$ & PXD000288 ${ }^{[19]}$ & Triceps muscles & $\begin{array}{l}\text { Triceps } \\
\text { Muscles } \\
\end{array}$ & Mus musculus & $\mathrm{C} 57 \mathrm{BL} / 6$ & 36 & 3 & 10,870 & 189,553 & 126,670 & 6,421 \\
\hline E-PROT-16 & PXD003155 ${ }^{[20]}$ & $\begin{array}{l}\text { Cerebellum, } \\
\text { Liver }\end{array}$ & $\begin{array}{l}\text { Brain, } \\
\text { Liver }\end{array}$ & Mus musculus & C57BL/6 & 24 & 12 & 4,508 & 59,696 & 45,728 & 3,797 \\
\hline E-PROT-74 & PXD004612 [21] & $\begin{array}{l}\text { Achilles and } \\
\text { Plantaris tendon }\end{array}$ & Tendon & Mus musculus & $\mathrm{C} 57 \mathrm{BL} / 6$ & 8 & 8 & 457 & 6,643 & 3,271 & 273 \\
\hline E-PROT-75 & PXD005230 [22] & $\begin{array}{l}\text { Hippocampus, } \\
\text { Cerebellum, } \\
\text { Cortex }\end{array}$ & Brain & Mus musculus & $\mathrm{C} 57 \mathrm{BL} / 10 \mathrm{~J}$ & 72 & 36 & 7,663 & 63,479 & 41,683 & 6,037 \\
\hline E-PROT-76 & PXD009909 [23] & Retina & Eye & Mus musculus & $\begin{array}{l}\text { ND4 Swiss } \\
\text { Webster }\end{array}$ & 12 & 1 & 5,002 & 29,454 & 24,961 & 3,686 \\
\hline E-PROT-77 & PXD012307 ${ }^{[24]}$ & Lung & Lung & Mus musculus & $\mathrm{C} 57 \mathrm{BL} / 6$ & 32 & 2 & 6,809 & 106,391 & 73,950 & 5,795 \\
\hline E-PROT-78 & PXD009639 ${ }^{[25]}$ & Lens & Eye & Mus musculus & $\mathrm{CD} 1$ & 10 & 1 & 4,519 & 20,779 & 18,006 & 3,064 \\
\hline E-PROT-79 & PXD019394 [26] & $\begin{array}{l}\text { Heart, Kidney, } \\
\text { Liver, Lung, } \\
\text { Brain, Spleen, } \\
\text { Testis, Pancreas }\end{array}$ & $\begin{array}{l}\text { Heart, } \\
\text { Kidney, } \\
\text { Liver, } \\
\text { Lung, } \\
\text { Brain, } \\
\text { Spleen, } \\
\text { Testis, } \\
\text { Pancreas }\end{array}$ & Mus musculus & $\begin{array}{l}\text { Swiss- } \\
\text { Webster }\end{array}$ & 96 & 8 & 9,853 & 141,506 & 105,701 & 8,185 \\
\hline E-PROT-81 & PXD012636 ${ }^{[27]}$ & $\begin{array}{l}\text { Left atrium, } \\
\text { Left ventricle, } \\
\text { Right atrium, } \\
\text { Right ventricle }\end{array}$ & Heart & Mus musculus & $\mathrm{C} 57 \mathrm{BL} / 6$ & 120 & 4 & 7,772 & 146,966 & 99,577 & 6,435 \\
\hline E-PROT-82 & PXD019431 & $\begin{array}{l}\text { Articular } \\
\text { cartilage }\end{array}$ & $\begin{array}{l}\text { Articular } \\
\text { cartilage }\end{array}$ & Mus musculus & $\mathrm{BALB} \backslash \mathrm{c}$ & 72 & 6 & 1,815 & 17,695 & 15,191 & 1,518 \\
\hline E-PROT-83 & PXD022614 [29] & Brain & Brain & Mus musculus & $\begin{array}{l}\text { C57BL/6J: } \\
\mathrm{Rj}\end{array}$ & 120 & 6 & 6,645 & 97,443 & 69,884 & 5,673 \\
\hline
\end{tabular}




\begin{tabular}{|c|c|c|c|c|c|c|c|c|c|c|c|}
\hline & & & & & $\begin{array}{l}\text { C57BL/6JR } \\
\text { ccHsd }\end{array}$ & & & & & & \\
\hline E-PROT-84 & PXD004496 [30] & Hippocampus & Brain & Mus musculus & $\mathrm{C} 57 \mathrm{BL} / 6 \mathrm{~J}$ & 204 & 17 & 4,192 & 37,363 & 30,100 & 3,424 \\
\hline E-PROT-85 & PXD008736 ${ }^{[31]}$ & $\begin{array}{l}\text { Right atrium, } \\
\text { Sinus node }\end{array}$ & Heart & Mus musculus & $\mathrm{C} 57 \mathrm{BL} / 6 \mathrm{~J}$ & 143 & 6 & 7,906 & 144,926 & 94,379 & 6,554 \\
\hline E-PROT- $86^{\S}$ & PXD012677 ${ }^{[32]}$ & Amygdala & Brain & $\begin{array}{l}\text { Rattus } \\
\text { norvegicus }\end{array}$ & $\begin{array}{l}\text { Sprague } \\
\text { Dawley }\end{array}$ & 3 & 3 & 1,872 & 15,326 & 12,367 & 1,382 \\
\hline E-PROT-87§ & PXD006692 ${ }^{[33]}$ & Lung & Lung & $\begin{array}{l}\text { Rattus } \\
\text { norvegicus }\end{array}$ & $\begin{array}{l}\text { Sprague } \\
\text { Dawley }\end{array}$ & 10 & 10 & 2,079 & 14,440 & 11,696 & 1,398 \\
\hline E-PROT- $88^{\S}$ & PXD016793 ${ }^{[34]}$ & Liver & Liver & $\begin{array}{l}\text { Rattus } \\
\text { norvegicus }\end{array}$ & $\begin{array}{l}\text { Sprague } \\
\text { Dawley }\end{array}$ & 8 & 8 & 4,787 & 57,998 & 46,411 & 3,743 \\
\hline E-PROT- $89^{\S}$ & PXD004364 ${ }^{[35]}$ & Testis & Testis & $\begin{array}{l}\text { Rattus } \\
\text { norvegicus }\end{array}$ & $\begin{array}{l}\text { Sprague } \\
\text { Dawley }\end{array}$ & 3 & 3 & 2,351 & 15,880 & 13,674 & 1,601 \\
\hline E-PROT-91 & PXD001839 [36] & Left ventricle & Heart & $\begin{array}{l}\text { Rattus } \\
\text { norvegicus }\end{array}$ & F344/BN & 12 & 12 & 1,345 & 10,310 & 8,804 & 925 \\
\hline E-PROT-92 ${ }^{\S}$ & PXD013543 [37] & Left ventricle & Heart & $\begin{array}{l}\text { Rattus } \\
\text { norvegicus }\end{array}$ & Wistar & 8 & 8 & 1,858 & 17,303 & 13,622 & 1,340 \\
\hline E-PROT-93 & PXD016958 ${ }^{[38]}$ & $\begin{array}{l}\text { First segment of } \\
\text { proximal tubule, } \\
\text { second segment } \\
\text { of proximal } \\
\text { tubule, third } \\
\text { segment of } \\
\text { proximal tubule, } \\
\text { medullary thick } \\
\text { ascending limb, } \\
\text { cortical thick } \\
\text { ascending limb, } \\
\text { distal } \\
\text { convoluted } \\
\text { tubule, } \\
\text { connecting } \\
\text { tubule, cortical } \\
\text { collecting duct, } \\
\text { outer medullary } \\
\text { collecting duct, } \\
\text { inner medullary } \\
\text { collecting duct }\end{array}$ & Kidney & $\begin{array}{l}\text { Rattus } \\
\text { norvegicus }\end{array}$ & $\begin{array}{l}\text { Sprague } \\
\text { Dawley }\end{array}$ & 132 & 32 & 7,846 & 103,886 & 83,662 & 6,130 \\
\hline
\end{tabular}




\begin{tabular}{|c|c|c|c|c|c|c|c|c|c|c|c|}
\hline E-PROT-94 & PXD003375 [39] & $\begin{array}{l}\text { Caudal and } \\
\text { rostral segments } \\
\text { of spinal cord }\end{array}$ & Spinal cord & $\begin{array}{l}\text { Rattus } \\
\text { norvegicus }\end{array}$ & Wistar & 21 & 18 & 2,477 & 29,213 & 22,025 & 1,926 \\
\hline E-PROT-95 & PXD015928 [40] & Tendon & Tendon & $\begin{array}{l}\text { Rattus } \\
\text { norvegicus }\end{array}$ & Wistar & 3 & 3 & 199 & 1,253 & 1,063 & 101 \\
\hline TOTAL & $\begin{array}{l}23 \text { datasets } \\
\text { (Mouse: } 14 \text {, } \\
\text { Rat: 9) }\end{array}$ & $\begin{array}{l}34 \text { tissues } \\
\text { (Mouse: 21, } \\
\text { Rat: 18) }\end{array}$ & $\begin{array}{l}14 \text { organs } \\
\text { (Mouse: } 12 \text {, } \\
\text { Rat: } 8 \text { ) }\end{array}$ & & & $\begin{array}{l}1,173 \mathrm{MS} \\
\text { runs } \\
\text { (Mouse: 973, } \\
\text { Rat: 200) }\end{array}$ & $\begin{array}{l}211 \text { samples } \\
\text { (Mouse: 114, } \\
\text { Rat: 97) }\end{array}$ & & & & \\
\hline
\end{tabular}

144 Table 1. List of mouse and rat proteomics datasets that were re-analysed. ${ }^{\S}$ Only normal/untreated samples within this dataset are reported in this

145 study. However, results from both normal and disease samples are available in Expression Atlas. $†$ Numbers after post-processing. 


\subsection{Protein coverage across organs and datasets}

148 One of the main aims of this study was to study protein expression across various organs. To

149 enable simplicity of comparison [15] we first grouped 34 different tissues into 14 distinct

150 organs, as discussed in 'Methods'. We defined 'tissue' as a distinct functional or structural region within an 'organ'. We estimated the number of 'canonical proteins' identified across organs by first mapping all members of each protein group to their respective parent genes.

We defined the parent gene as equivalent to the UniProt 'canonical protein' and we will denote the term 'protein abundance' to mean 'canonical protein abundance' from here on in the manuscript.

\subsubsection{Mouse proteome}

A total of 21,274 protein groups were identified from mouse datasets, among which 8,176 protein groups $(38.4 \%)$ were uniquely present in only one organ and 70 protein groups $(0.3 \%)$ were ubiquitously observed (see the full list in Supplementary file 2$)$. Mouse protein groups were mapped to 12,570 genes (canonical proteins) (Supplementary file 3 ). We detected the largest number of canonical proteins in samples from liver $(9,920,78.9 \%$ of the total) and the lowest numbers in samples from tendon $(273,2.2 \%)$ and articular cartilage $(1,519,12.1 \%)$ (Fig. 2A). The lower number of proteins identified in tendon could be attributed to the smallest sample size (only one sample out of $114,0.9 \%$ ). Also, tendon is a

166 relatively hypocellular tissue, which has a low protein turnover rate. Dataset PXD000867,

167 containing mouse liver samples, had the highest number of canonical proteins detected

$168(9,715,77.3 \%)$, while the least number of proteins were detected in dataset PXD004612

169 (tendon, 273, 2.2\%), as highlighted above (Fig. 2B). 
171 We studied the normalised protein abundance distribution in organs (Fig. 2C) and found that

172 all organs, except tendon, had similar median abundances. However, one cannot attribute

173 biological meaning to these observations, since the method of normalisation by definition

174 fixes each sample to have the same "total abundance", which then gets shared out amongst all

175 proteins. The normalised protein abundance distribution in datasets indicated a higher than median abundances detected in datasets PXD004612 (tendon) and PXD003164 (testis) (Fig.

We found a large number of proteins uniquely present in one organ (Fig. 2F).

180

A

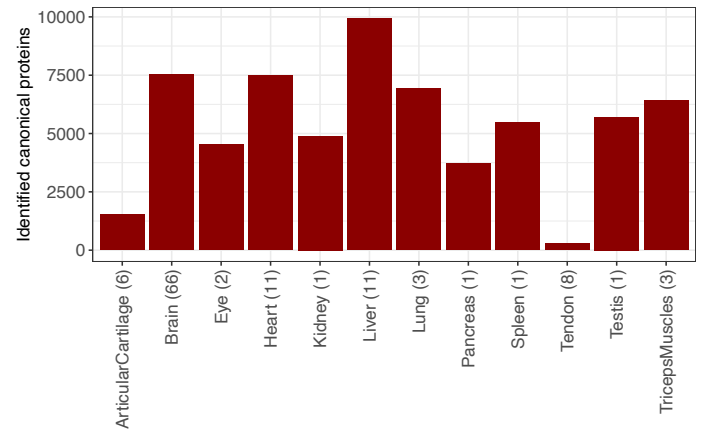

B

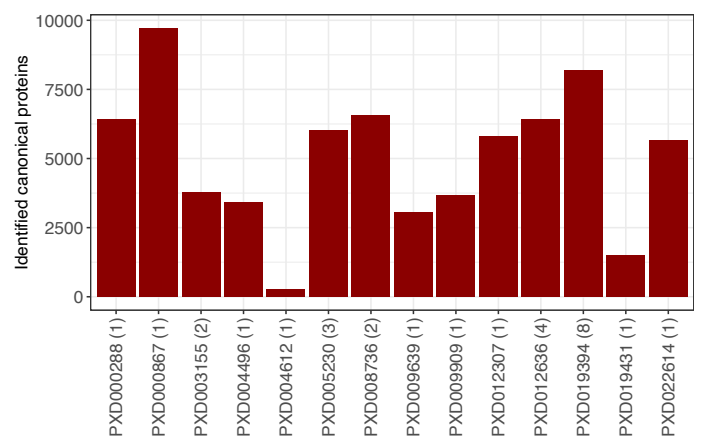

E

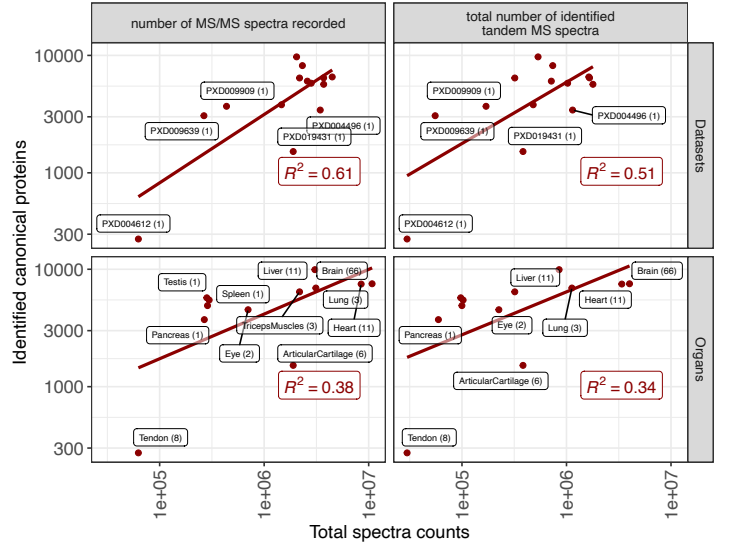

C

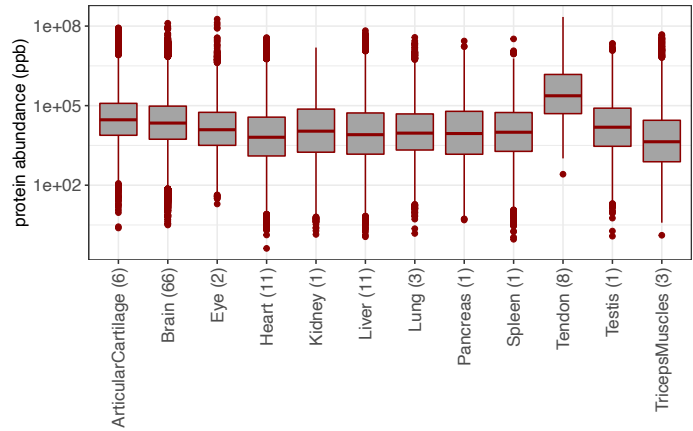

D

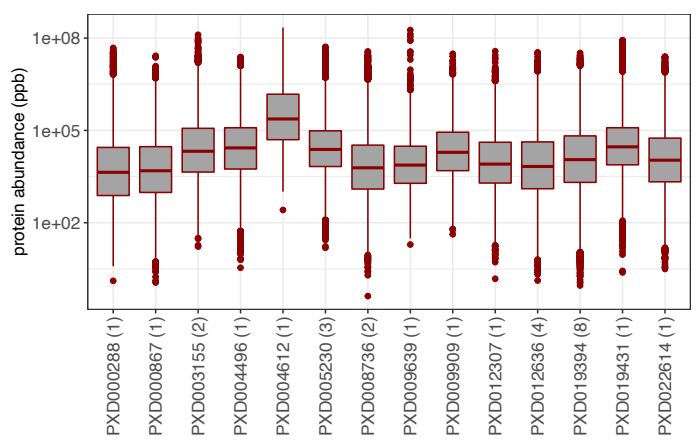

$\mathrm{F}$

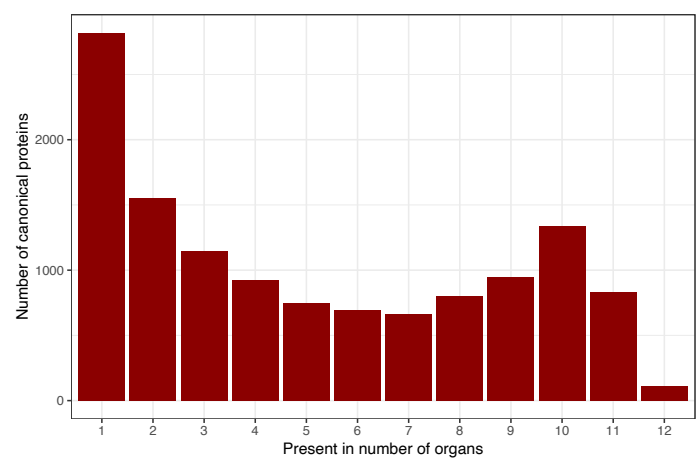


182 Figure 2. (A) Number of canonical proteins identified across different mouse organs. The number within the parenthesis indicates the number of samples. (B) Canonical proteins identified across different datasets. The number within the parenthesis indicate the number of unique tissues in the dataset. (C) Range of normalised iBAQ protein abundances across different organs. The number within the parenthesis indicates the number of samples. (D)

187 Range of normalised iBAQ protein abundances across different datasets. The number within parenthesis indicate the number of unique tissues in the dataset. (E) Comparison of total spectral data with the number of canonical proteins identified in each dataset and organ. $(\mathrm{F})$ Distribution of canonical proteins identified across organs.

\subsubsection{Rat proteome}

193 A total of 7,769 protein groups were identified across 8 different rat organs among which $3,649(46.9 \%)$ protein groups were unique to one specific organ while $13(0.16 \%)$ protein groups were present among all organs (see full list in Supplementary file 2). The protein groups were mapped to 7,116 genes (canonical proteins) (Supplementary file 3). The highest number of canonical proteins $(6,106,85.1 \%)$ was found in rat kidney samples. The lowest number of canonical proteins $(101,1.4 \%)$ was found in samples from tendon, as shown in is interesting to note that large number of canonical proteins were detected in liver samples,

202 which relatively has fewer number of samples, when compared to number of samples in heart or spinal cord.

Datasets PXD016958 and PXD016793 consisted entirely of kidney and liver samples, 
(Fig. 3B). The normalised protein abundances were similar among the various organs and proteins identified and the MS spectra identified (Fig. 3E). As seen in mouse datasets, we also observed a large number of proteins uniquely present in one organ (Fig. 3F).

A

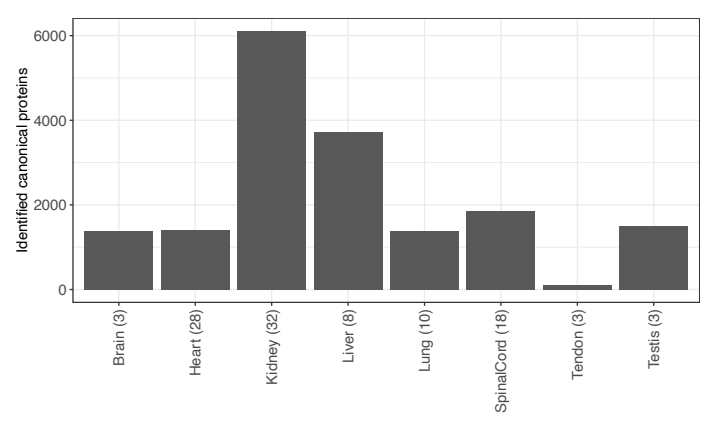

B

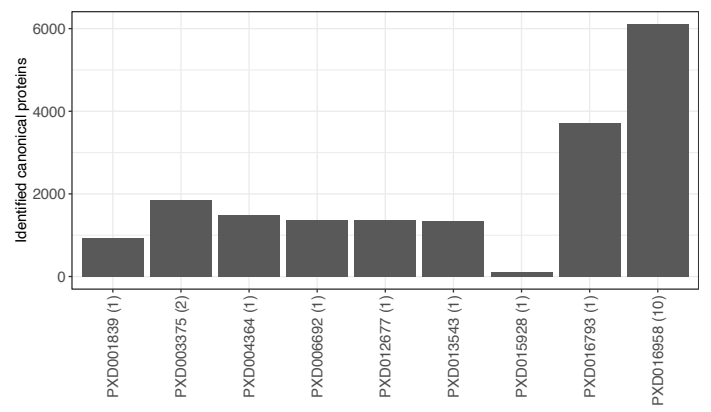

$E$

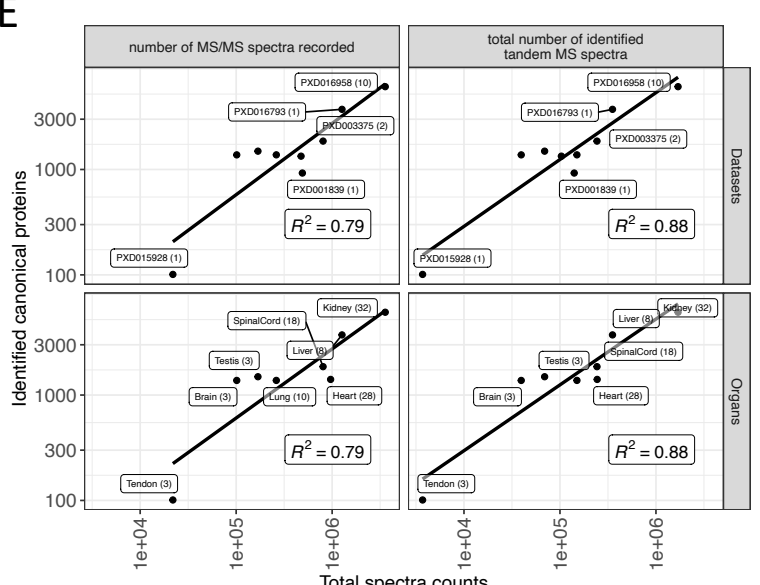

C

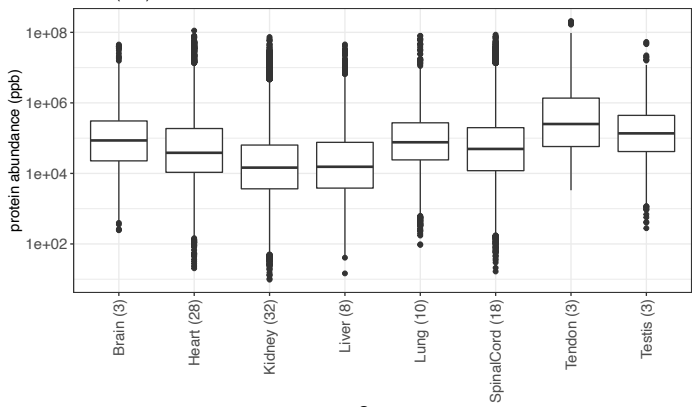

D

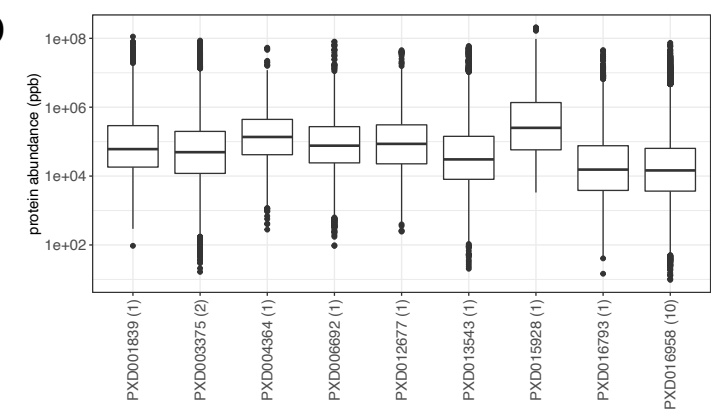

$\mathrm{F}$

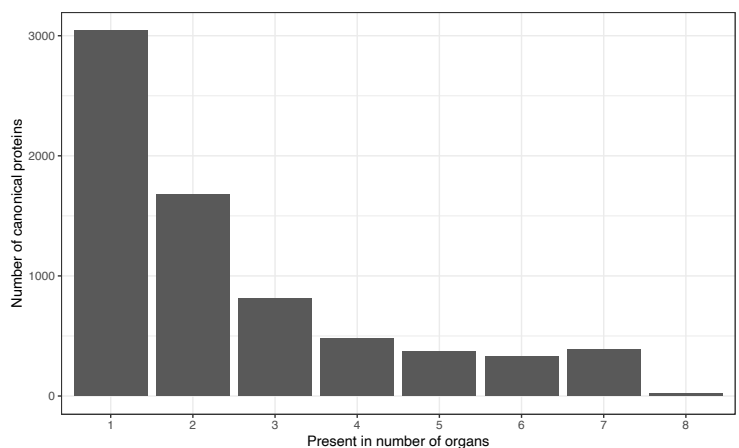

Figure 3. (A) Number of canonical proteins identified across different rat organs. The

214 number within the parenthesis indicates the number of samples. (B) Canonical proteins

215 identified across different datasets. The number within the parenthesis indicate the number of

216 unique tissues in the dataset. (C) Range of normalised iBAQ protein abundances across 
218 Range of normalised iBAQ protein abundances across different datasets. The number within

219 parenthesis indicate the number of unique tissues in the dataset. (E) Comparison of total

220 spectral data with the number of canonical proteins identified in each dataset and organ. (F)

221 Distribution of canonical proteins identified across organs.

\subsection{Protein abundance comparison across organs}

224 Next, we studied how protein abundances compared across different datasets and organs. The presence of batch effects between datasets makes this type of comparisons challenging. To aid comparison of protein abundances between datasets we transformed the normalised iBAQ intensities into ranked bins as explained in 'Methods', i.e., proteins in bin 5 are highly abundant while proteins in bin 1 are expressed in lower abundances.

\subsubsection{Mouse proteome}

231 We found that $1,086(8.6 \%)$ proteins were found with their highest expression in at least 3 organs, with a median bin value greater than 4 (Supplementary file 3). On the other end of the scale, $138(1.1 \%)$ canonical proteins were found with their lowest expression in at least 3 organs, with a median bin value less than 2 . The bin transformed abundances in all organs are provided in Supplementary file 3.

237 To compare protein expression across all organs in mouse, we calculated pairwise Pearson correlation coefficients (rp) across 117 samples (Fig. 4A). We observed a good correlation of protein expression within the brain (median $\mathrm{rp}=0.55)$ and heart (median $\mathrm{rp}=0.82)$ samples.

We performed PCA on all samples from mouse datasets for testing the effectiveness of bin

241 transformation method in reducing batch effects. Fig. 4B shows the clustering of samples 
bioRxiv preprint doi: https://doi.org/10.1101/2021.12.20.473413; this version posted December 21, 2021. The copyright holder for this preprint (which was not certified by peer review) is the author/funder, who has granted bioRxiv a license to display the preprint in perpetuity. It is made available under aCC-BY-NC-ND 4.0 International license.

242 from various organs of mouse. We observed samples from the same organ clustered together.

243 For example, we can observe that brain samples all clustered together in one group, although

244 they come from different datasets (Fig. 4C). However, we also observed that samples from

245 other organs such as liver, did not cluster according to their organ types but clustered together

246 with the dataset they were part of, indicating the presence of residual batch effects.

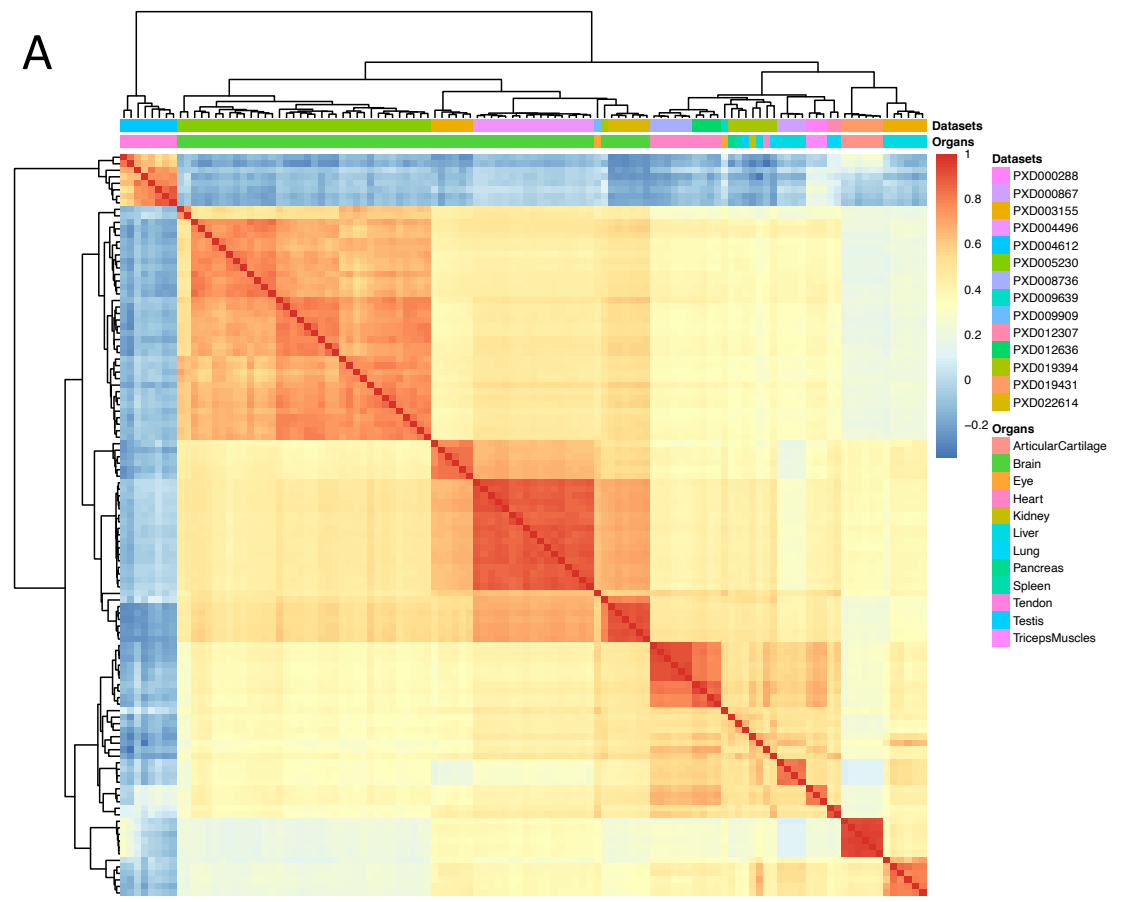

B

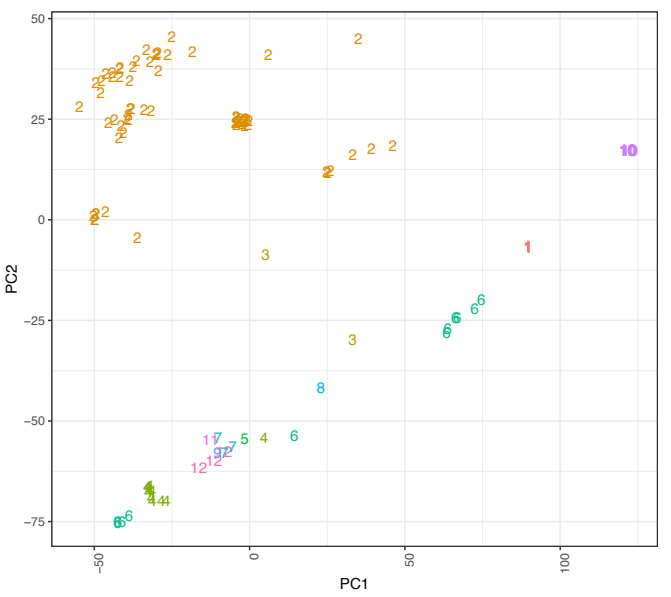

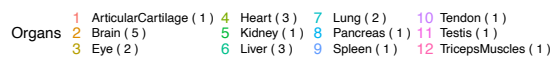
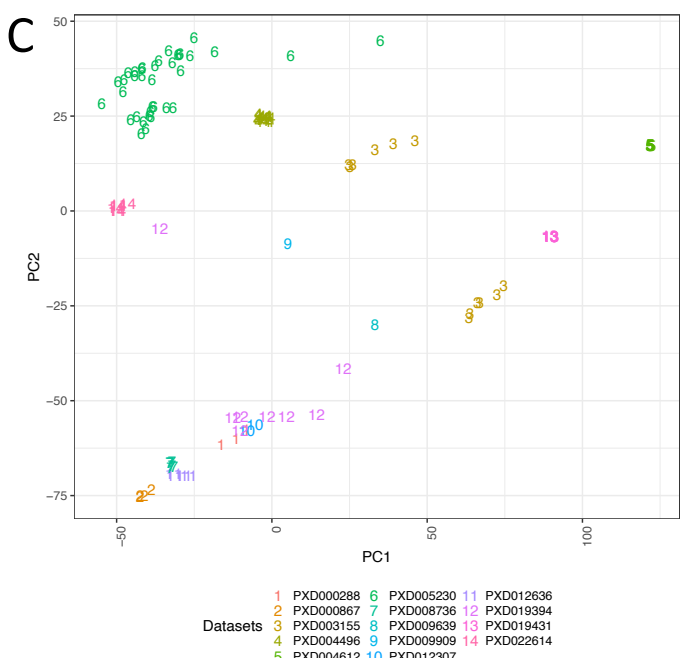

249 Figure 4. (A) Heatmap of pairwise Pearson correlation coefficients across all mouse samples.

250 The colour represents the correlation coefficient and was calculated using the bin transformed 
251 iBAQ values. The samples were hierarchically clustered on columns and rows using

252 Euclidean distances. (B) PCA of all samples coloured by the organ types. (C) PCA of all

253 samples coloured by their respective dataset identifiers. The numbers in parenthesis indicate

254 the number of datasets for each organ. Binned values of canonical proteins quantified in at

255 least $50 \%$ of the samples were used to perform the PCA.

256

257

\subsubsection{Rat proteome}

258 Similarly, in rat, on one hand, $311(4.3 \%)$ proteins were found with highest expression in at

259 least 3 organs with a median bin value greater than 4 . On the other hand, $27(0.37 \%)$

260 canonical proteins were found with their lowest expression in at least 3 organs, with a median

261 bin value of less than 2 . The bin transformed abundances in all organs are provided in

262 Supplementary file 3.

263

264 The samples from rat datasets were also better correlated among each other (Fig. 5A) than in

265 the case of mouse. We observed a good correlation of protein expression within samples from

266 liver (median Pearson's correlation $\mathrm{rp}=0.92$ ), lung (median $\mathrm{rp}=0.84$ ), spinal cord (median

$267 \mathrm{rp}=0.80)$, heart (median $\mathrm{rp}=0.84)$ and brain $($ median $\mathrm{rp}=0.93)$. We also observed a good

268 clustering in the PCA of samples coming from the same organ type (Fig. 5B). Kidney, lung,

269 spinal cord and heart samples all clustered together according to their organ type. Fig. 5C

270 shows the samples based on the dataset they are part of. However, most organ samples are

271 part of individual datasets except samples from heart, which came from two datasets

272 (PXD001839 and PXD013543). Fig. 5C shows that the heart samples clustered into two

273 groups, wherein each cluster included samples from a different dataset. 


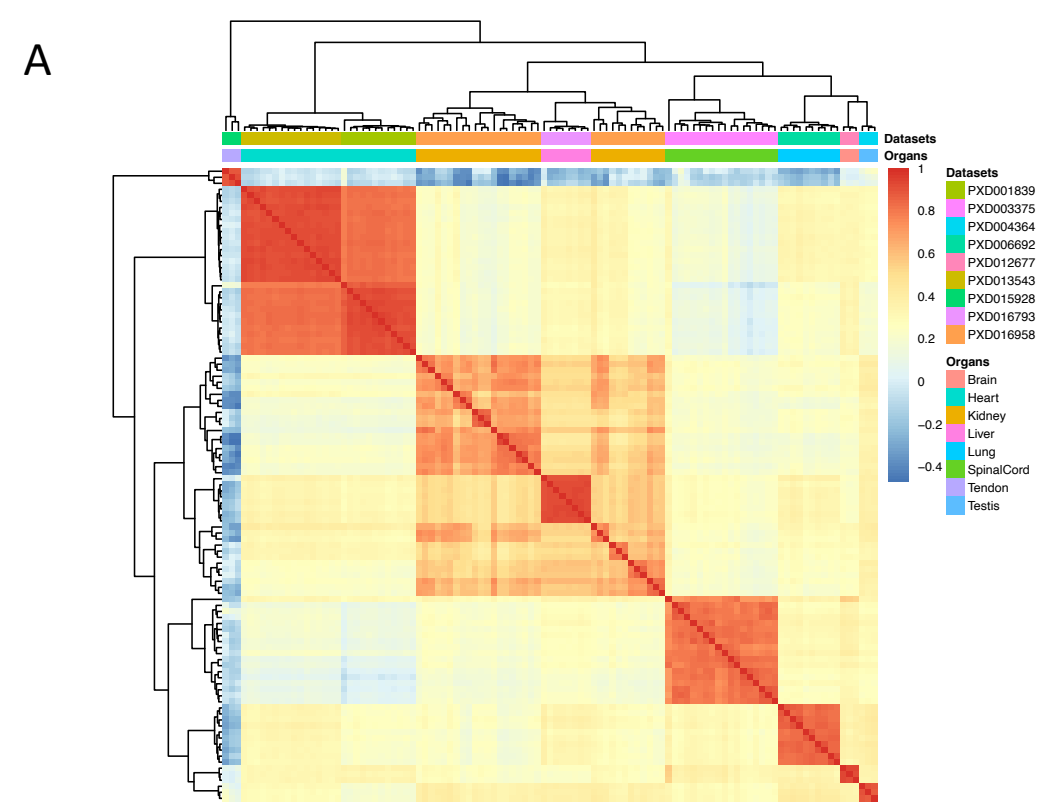

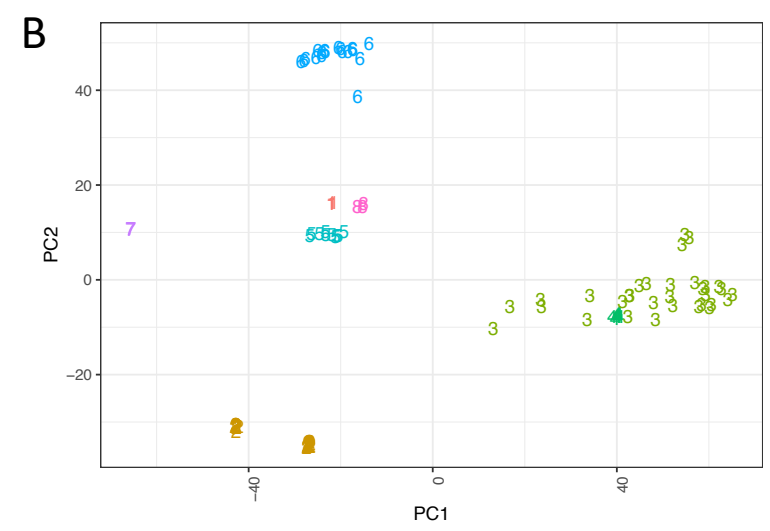

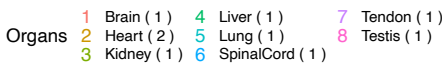

C

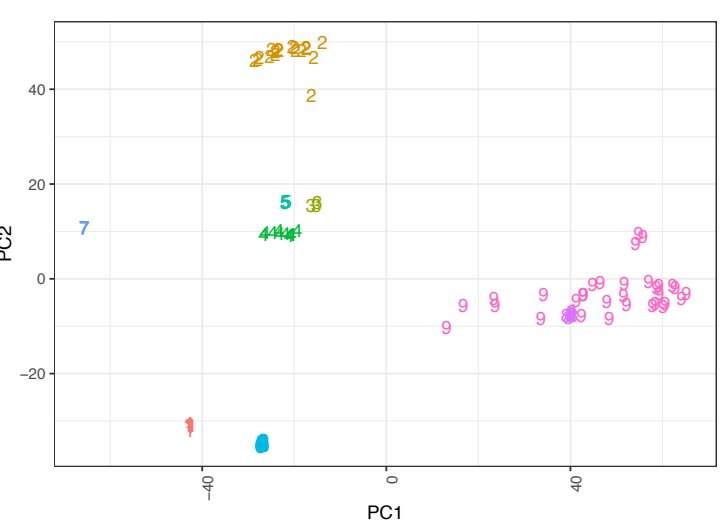

Datasets 1 PXD001839 4 PXD006692 7 PXD015928

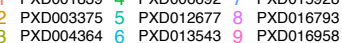

275 Figure 5. (A) Heatmap of pairwise Pearson correlation coefficients across all rat samples.

276 The colour represents the correlation coefficient and was calculated using the bin transformed

277 iBAQ values. The samples were hierarchically clustered on columns and rows using

278 Euclidean distances. (B) PCA of all samples coloured by the organ types. (C) PCA of all

279 samples coloured by their respective dataset identifiers. The numbers in parenthesis indicate

280 the number of datasets for each organ. Binned values of canonical proteins quantified in at

281 least $50 \%$ of the samples were used to perform the PCA. 
bioRxiv preprint doi: https://doi.org/10.1101/2021.12.20.473413; this version posted December 21, 2021. The copyright holder for this preprint (which was not certified by peer review) is the author/funder, who has granted bioRxiv a license to display the preprint in perpetuity. It is made available under aCC-BY-NC-ND 4.0 International license.

284 Based on their expression, canonical proteins were classified into three different groups based on their organ specificity: "mixed", "group-enriched" and "organ-enriched" (see

286 Supplementary file 4). We considered over-expressed canonical proteins in each organ as

287 those which were in "group-enriched" and "organ-enriched". The analysis showed that on

288 average, $20.8 \%$ and $26.0 \%$ of the total elevated canonical proteins were organ group-specific

289 in mouse and rat, respectively (Fig. 6). In addition, $4.3 \%$ and $14.2 \%$ were unique organ-

290 enriched in mouse and rat, respectively. The highest ratio of organ-enriched in mouse was

291 found in liver (13.6\%), whereas it was found in kidney in rat (39.8\%).

292 We then performed a gene ontology (GO) enrichment analysis of those proteins that were

293 'organ-enriched' and group-enriched' using GO terms associated with biological processes.

294 We found 1,036 GO terms to be statistically significant in all organs, as seen in

295 Supplementary file 5. The most significant GO terms for each organ are shown in Table 2.

296
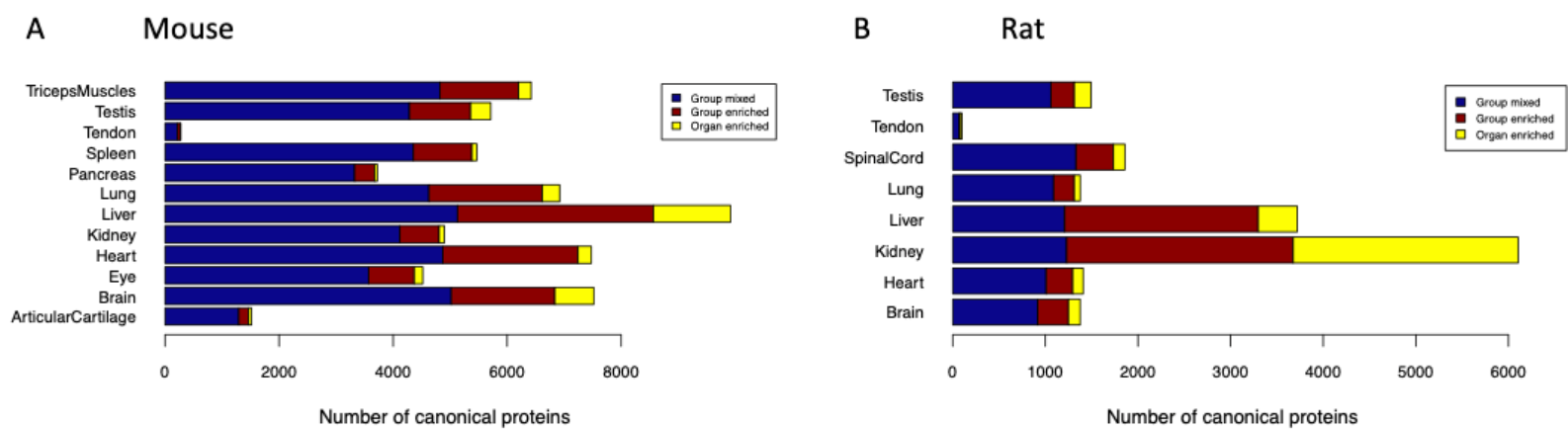

297

298 Figure 6. Organ specificity of canonical proteins in (A) mouse and (B) rat.

\begin{tabular}{|l|l|l|l|l|}
\hline Organ & Species & GO ID & Description & $\begin{array}{l}\text { adjusted p- } \\
\text { value }\end{array}$ \\
\hline $\begin{array}{l}\text { Articular } \\
\text { cartilage }\end{array}$ & Mus musculus & $\begin{array}{l}\text { GO:0030198 } \\
\text { GO:0043062 } \\
\text { GO:0045229 }\end{array}$ & $\begin{array}{l}\text { Extracellular matrix organization } \\
\text { Extracellular structure organization } \\
\text { External encapsulating structure organization }\end{array}$ & $\begin{array}{l}8.94 * 10^{-38} \\
8.94 * 10^{-38} \\
8\end{array}$ \\
\hline \multirow{3}{*}{ Brain } & Mus musculus & GO:0050804 & $\begin{array}{l}\text { Modulation of chemical synaptic } \\
\text { transmission }\end{array}$ & $7.03 * 10^{-65}$ \\
& & GO:0099177 & $\begin{array}{l}\text { Gegulation of trans-synaptic signalling } \\
\text { Gynapse organization }\end{array}$ & $7.03 * 10^{-65}$ \\
& & & $1.41 * 10^{-48}$ \\
\hline
\end{tabular}


bioRxiv preprint doi: https://doi.org/10.1101/2021.12.20.473413; this version posted December 21, 2021. The copyright holder for this preprint (which was not certified by peer review) is the author/funder, who has granted bioRxiv a license to display the preprint in perpetuity. It is made available under aCC-BY-NC-ND 4.0 International license.

\begin{tabular}{|c|c|c|c|c|}
\hline Heart & Mus musculus & $\begin{array}{l}\text { GO:0060047 } \\
\text { GO:0008016 } \\
\text { GO:0060537 }\end{array}$ & $\begin{array}{l}\text { Heart contraction } \\
\text { Regulation of heart contraction } \\
\text { Muscle tissue development }\end{array}$ & $\begin{array}{l}7.10^{*} 10^{-11} \\
4.43 * 10^{-10} \\
6.16^{*} 10^{-10}\end{array}$ \\
\hline Kidney & Mus musculus & $\begin{array}{l}\text { GO:0015711 } \\
\text { GO:0044282 } \\
\text { GO:0016054 }\end{array}$ & $\begin{array}{l}\text { Organic anion transport } \\
\text { Small molecule catabolic process } \\
\text { Organic acid catabolic process }\end{array}$ & $\begin{array}{l}4.59 * 10^{-19} \\
4.91 * 10^{-15} \\
6.25 * 10^{-15}\end{array}$ \\
\hline Eye & Mus musculus & $\begin{array}{l}\text { GO:0007601 } \\
\text { GO:0001654 } \\
\text { GO:0099504 }\end{array}$ & $\begin{array}{l}\text { Visual perception } \\
\text { Eye development } \\
\text { Synaptic vesicle cycle }\end{array}$ & $\begin{array}{l}7.54 * 10^{-50} \\
5.31 * 10^{-31} \\
8.36 * 10^{-18}\end{array}$ \\
\hline Liver & Mus musculus & $\begin{array}{l}\text { GO:0016569 } \\
\text { GO:0016570 } \\
\text { GO:0019369 }\end{array}$ & $\begin{array}{l}\text { Covalent chromatin modification } \\
\text { Histone modification } \\
\text { Arachidonic acid metabolic process }\end{array}$ & $\begin{array}{l}6.26 * 10^{-10} \\
1.71 * 10^{-08} \\
1.71 * 10^{-08}\end{array}$ \\
\hline Lung & Mus musculus & $\begin{array}{l}\text { GO:0120031 } \\
\text { GO:0030031 } \\
\text { GO:0044782 }\end{array}$ & $\begin{array}{l}\text { Plasma membrane bounded cell projection } \\
\text { assembly } \\
\text { Cell projection assembly } \\
\text { Cilium organization }\end{array}$ & $\begin{array}{l}3.61 * 10^{-14} \\
3.61 * 10^{-14} \\
9.83 * 10^{-14}\end{array}$ \\
\hline Pancreas & Mus musculus & $\begin{array}{l}\text { GO:0007586 } \\
\text { GO:0032328 }\end{array}$ & $\begin{array}{l}\text { Digestion } \\
\text { Alanine transport }\end{array}$ & $\begin{array}{l}0.005 \\
0.018\end{array}$ \\
\hline Spleen & Mus musculus & $\begin{array}{l}\text { GO:0046649 } \\
\text { GO:0050776 } \\
\text { GO:0045087 }\end{array}$ & $\begin{array}{l}\text { Lymphocyte activation } \\
\text { Regulation of immune response } \\
\text { Innate immune response }\end{array}$ & $\begin{array}{l}4.12 * 10^{-22} \\
2.00 * 10^{-20} \\
2.23 * 10^{-20}\end{array}$ \\
\hline Tendon & Mus musculus & $\begin{array}{l}\text { GO:0003012 } \\
\text { GO:0050879 } \\
\text { GO:0050881 }\end{array}$ & $\begin{array}{l}\text { Muscle system process } \\
\text { Multicellular organismal movement } \\
\text { Musculoskeletal movement }\end{array}$ & $\begin{array}{l}1.46^{*} 10^{-25} \\
3.14 * 10^{-19} \\
1.46^{*} 10^{-25}\end{array}$ \\
\hline Testis & Mus musculus & $\begin{array}{l}\text { GO:0048232 } \\
\text { GO:0003341 } \\
\text { GO:0044782 }\end{array}$ & $\begin{array}{l}\text { Male gamete generation } \\
\text { Cilium movement } \\
\text { Cilium organization }\end{array}$ & $\begin{array}{l}8.75 * 10^{-49} \\
3.04 * 10^{-38} \\
6.78 * 10^{-37}\end{array}$ \\
\hline Triceps muscles & Mus musculus & $\begin{array}{l}\text { GO:0061061 } \\
\text { GO:0055002 } \\
\text { GO:0003009 }\end{array}$ & $\begin{array}{l}\text { Muscle structure development } \\
\text { Striated muscle cell development } \\
\text { Skeletal muscle contraction }\end{array}$ & $\begin{array}{l}1.56 * 10^{-14} \\
2.41 * 10^{-14} \\
3.53 * 10^{-14}\end{array}$ \\
\hline Brain & $\begin{array}{l}\text { Rattus } \\
\text { norvegicus }\end{array}$ & $\begin{array}{l}\text { GO:0099537 } \\
\text { GO:0007268 } \\
\text { GO:0098916 }\end{array}$ & $\begin{array}{l}\text { Trans-synaptic signalling } \\
\text { Chemical synaptic transmission } \\
\text { Anterograde trans-synaptic signalling }\end{array}$ & $\begin{array}{l}1.79 * 10^{-60} \\
1.79 * 10^{-60} \\
1.79 * 10^{-60}\end{array}$ \\
\hline Heart & $\begin{array}{l}\text { Rattus } \\
\text { norvegicus }\end{array}$ & $\begin{array}{l}\text { GO:0061061 } \\
\text { GO:0003012 } \\
\text { GO:0055001 }\end{array}$ & $\begin{array}{l}\text { Muscle structure development } \\
\text { Muscle system process } \\
\text { Muscle cell development }\end{array}$ & $\begin{array}{l}2.94 * 10^{-17} \\
6.30 * 10^{-16} \\
4.00 * 10^{-15}\end{array}$ \\
\hline Kidney & $\begin{array}{l}\text { Rattus } \\
\text { norvegicus }\end{array}$ & $\begin{array}{l}\text { GO:0006396 } \\
\text { GO:0045944 } \\
\text { GO:0006260 }\end{array}$ & $\begin{array}{l}\text { RNA processing } \\
\text { positive regulation of transcription by RNA } \\
\text { polymerase II } \\
\text { DNA replication }\end{array}$ & $\begin{array}{l}6.19 * 10^{-13} \\
7.29 * 10^{-06} \\
1.74 * 10^{-05}\end{array}$ \\
\hline Liver & $\begin{array}{l}\text { Rattus } \\
\text { norvegicus }\end{array}$ & $\begin{array}{l}\text { GO:0008202 } \\
\text { GO:0016054 } \\
\text { GO:0032787 }\end{array}$ & $\begin{array}{l}\text { Steroid metabolic process } \\
\text { Organic acid catabolic process } \\
\text { Monocarboxylic acid metabolic process }\end{array}$ & $\begin{array}{l}2.74 * 10^{-10} \\
1.61 * 10^{-09} \\
1.64 * 10^{-09}\end{array}$ \\
\hline Lung & $\begin{array}{l}\text { Rattus } \\
\text { norvegicus }\end{array}$ & $\begin{array}{l}\text { GO:0031589 } \\
\text { GO:0009617 } \\
\text { GO:0030036 }\end{array}$ & $\begin{array}{l}\text { Cell-substrate adhesion } \\
\text { Response to bacterium } \\
\text { Actin cytoskeleton organization }\end{array}$ & $\begin{array}{l}7.62 * 10^{-08} \\
7.62 * 10^{-08} \\
1.40 * 10^{-07}\end{array}$ \\
\hline Spinal cord & $\begin{array}{l}\text { Rattus } \\
\text { norvegicus }\end{array}$ & $\begin{array}{l}\text { GO:0061564 } \\
\text { GO:0099537 } \\
\text { GO:0007268 }\end{array}$ & $\begin{array}{l}\text { Axon development } \\
\text { Trans-synaptic signalling } \\
\text { Chemical synaptic transmission }\end{array}$ & $\begin{array}{l}4.26 * 10^{-18} \\
5.93 * 10^{-16} \\
5.93 * 10^{-16}\end{array}$ \\
\hline Tendon & $\begin{array}{l}\text { Rattus } \\
\text { norvegicus }\end{array}$ & $\begin{array}{l}\text { GO:0030199 } \\
\text { GO:0061448 } \\
\text { GO:0001501 }\end{array}$ & $\begin{array}{l}\text { Collagen fibril organization } \\
\text { Connective tissue development } \\
\text { Skeletal system development }\end{array}$ & $\begin{array}{l}1.23 * 10^{-13} \\
2.31 * 10^{-09} \\
3.39 * 10^{-09}\end{array}$ \\
\hline
\end{tabular}




\begin{tabular}{|l|l|l|l|l|}
\hline & & GO:0019953 & Sexual reproduction & $3.98 * 10^{-24}$ \\
Testis & Rattus & GO:0051704 & Multi-organism process & $1.61 * 10^{-18}$ \\
& norvegicus & GO:0007018 & Microtubule-based movement & $4.00^{*} 10^{-12}$ \\
\hline
\end{tabular}

301 Table 2. Analysis of the top three GO terms for each organ in mouse and rat using the

302 elevated organ-specific canonical proteins and group-specific as described in the 'Methods'

303 section.

\subsection{Protein abundances across orthologs in three species}

306 We had previously analysed 25 label-free proteomics datasets from healthy human samples to

307 assess baseline protein abundances in 14 organs following the same analytical methodology

308 [15]. We compared the expression of canonical proteins identified in all three organisms (rat,

309 mouse and human). Overall, 13,248 detected human genes (corresponding to the canonical

310 proteins) were compared with 12,570 genes detected in mouse and 7,116 genes detected in

311 rat. The number of orthologous mappings (i.e., "one-to-one" mappings, see 'Methods')

312 between rat, mouse and human genes are listed in table 3. We only considered one-to-one

313 mapped orthologues for the comparison of protein abundances.

\begin{tabular}{|c|c|c|c|c|c|c|c|}
\hline \multirow[b]{2}{*}{ Species } & \multirow[b]{2}{*}{$\begin{array}{c}\text { Identified } \\
\text { genes }\end{array}$} & \multirow{2}{*}{$\begin{array}{c}\text { Orthologs } \\
\text { of human } \\
\text { genes } \\
\text { identified } \\
\text { in [15] }\end{array}$} & \multicolumn{5}{|c|}{$\begin{array}{l}\text { Percentage of genes with different mapping against identified } \\
\text { human genes }\end{array}$} \\
\hline & & & one-to-one & $\begin{array}{l}\text { one-to- } \\
\text { many }\end{array}$ & $\begin{array}{l}\text { many-to- } \\
\text { many }\end{array}$ & $\begin{array}{l}\text { many-to- } \\
\text { one }\end{array}$ & not mapped \\
\hline $\begin{array}{l}\text { Mus } \\
\text { musculus }\end{array}$ & 12,570 & 10,601 & $80.4 \%$ & $1.9 \%$ & $0.56 \%$ & $1.46 \%$ & $15.7 \%$ \\
\hline $\begin{array}{l}\text { Rattus } \\
\text { norvegicus }\end{array}$ & 7,116 & 6,058 & $82.0 \%$ & $2.2 \%$ & $0.70 \%$ & $0.25 \%$ & $14.9 \%$ \\
\hline
\end{tabular}

316 Table 3. Homologs identified in mouse and rat datasets when compared with the background

317 list of genes identified in human datasets (Supplementary file 2 in [15]). 
318 Among human and mouse orthologues we observed relatively high levels of correlation of

319 protein abundances in brain $\left(\mathrm{R}^{2}=0.61\right)$, heart $\left(\mathrm{R}^{2}=0.65\right)$ and liver $\left(\mathrm{R}^{2}=0.56\right)$ (Fig. 7A).

320 Human and rat orthologs showed also relatively high levels of correlation in brain $\left(\mathrm{R}^{2}=\right.$

$3210.62)$, kidney $\left(\mathrm{R}^{2}=0.53\right)$ and liver $\left(\mathrm{R}^{2}=0.56\right)$, but almost no correlation in lung $\left(\mathrm{R}^{2}=0.12\right)$

322 and testis $\left(\mathrm{R}^{2}=0.18\right)($ Fig. $7 \mathrm{~B})$. Between mouse and rat orthologs, the correlation of protein

323 abundances was higher in liver $\left(\mathrm{R}^{2}=0.65\right)$, kidney $\left(\mathrm{R}^{2}=0.54\right)$ and brain $\left(\mathrm{R}^{2}=0.57\right)$ samples,

324 when compared to the samples coming from the rest of the organs (Fig. 7C). Fig. 7D shows

325 an illustration of some example comparisons of individual orthologs using binned protein

326 abundances.

327

328 For the same corresponding subsets, we also investigated the correlation of protein

329 expression between various organs within each organism. We observed that in general the

330 correlation of protein expression was slightly lower between organs within the same species,

331 when compared to a higher correlation, which was observed among orthologs

332 (Supplementary file 6). The found lower correlation of protein expression between different

333 organs was more apparent in mouse and rat.

335 Among the orthologs expressed in all organs in all three species, 747 (12.3\%) orthologs were

336 detected with a median bin expression value of more than 4, i.e., proteins that appear to have

337 conserved high expression in all organs and all tissues. Additionally, $13(0.2 \%)$ orthologs

338 were found with a median bin expression value less than 2 in all organs, although, it is harder

339 to detect consistently proteins with low abundances across all organs. A full list of the binned

340 protein abundances of orthologs is available in Supplementary file 7. The illustration of all

341 binned protein abundances across the three species is shown in Supplementary file 8. 

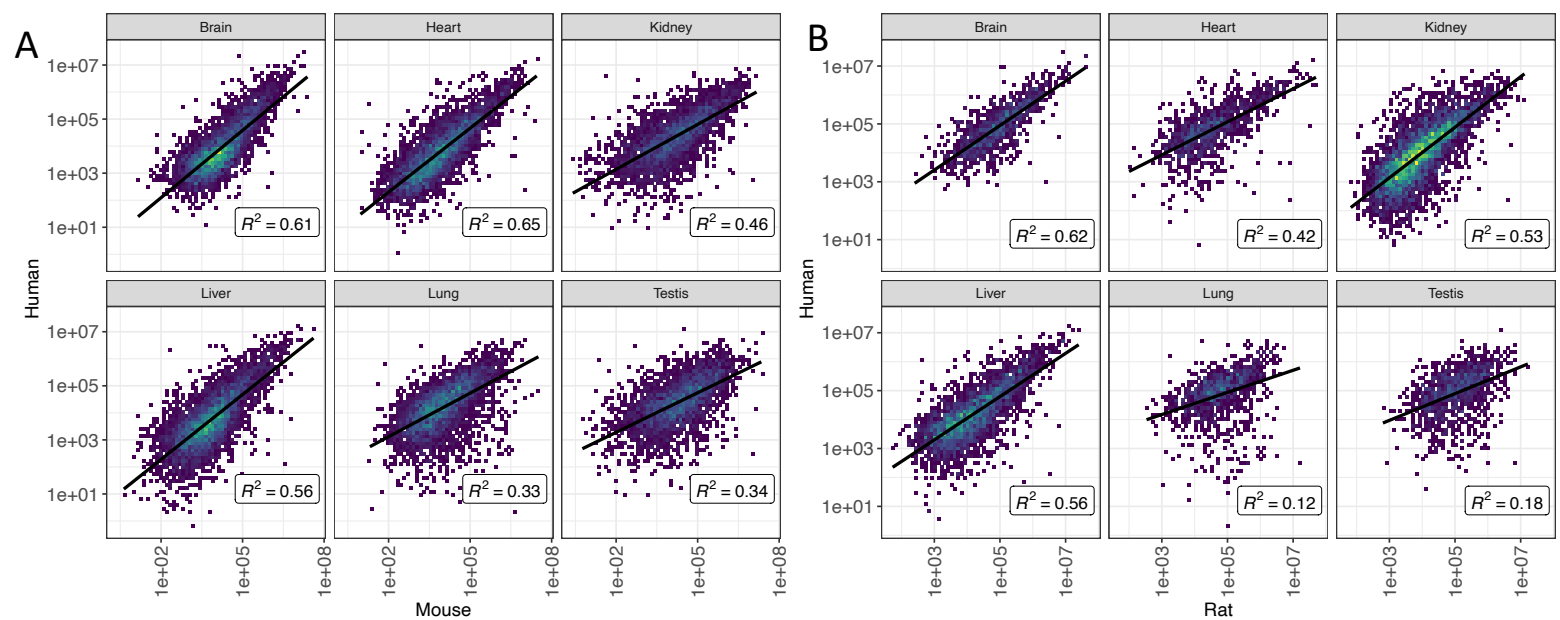

C
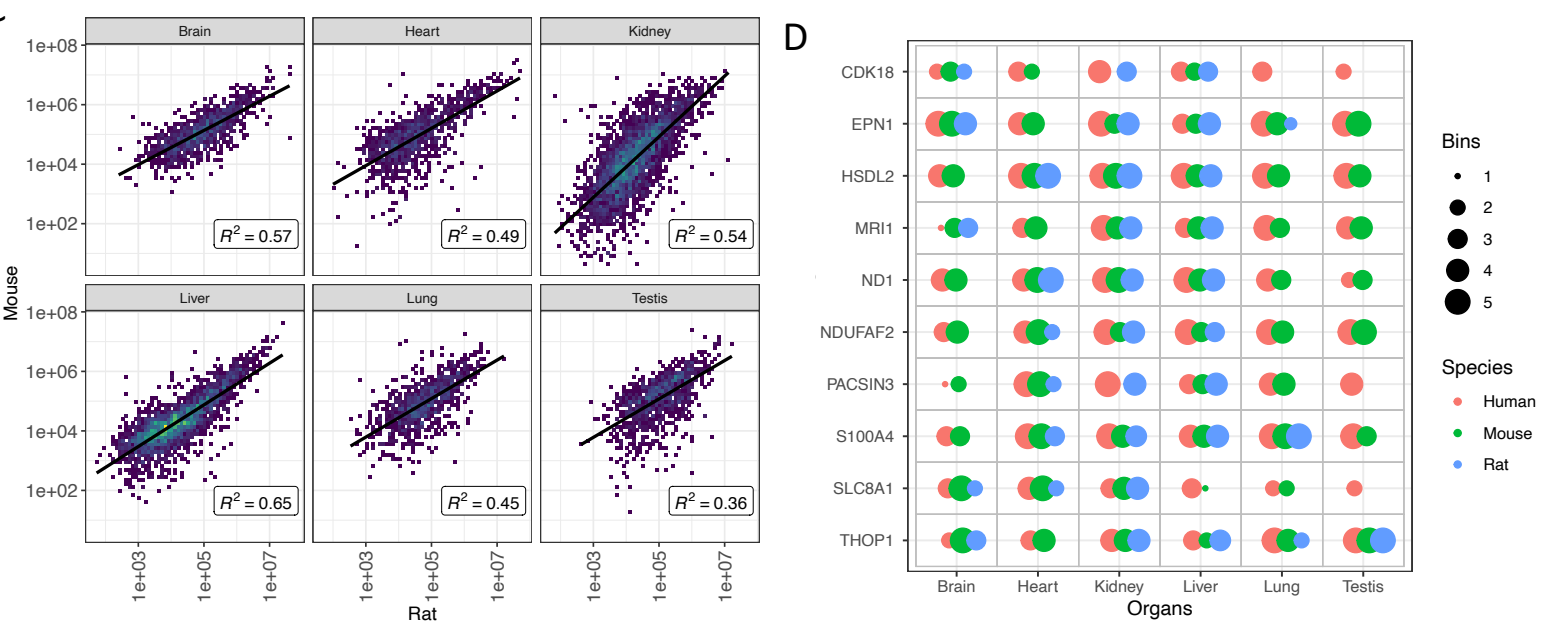

344 Figure 7. Comparison of protein abundances (in ppb) between one-to-one mapped orthologs of mouse, rat and human in various organs. (A) Pairwise correlation using normalised protein abundances of human and mouse orthologues. (B) Human and rat orthologs. (C) Mouse and rat orthologs. (D) As an example, the comparisons of binned protein expression of ten

348 randomly sampled orthologs are shown. All data corresponding to all cases (as reported in

349 panel D) are available in Supplementary file 7 and their corresponding illustration of binned values is available in Supplementary file 8. Orthologs in (D) are shown using their human Gene Symbol.

\subsection{Pathway enrichment analysis}

354 Based on the ortholog protein expression analysis described above, we mapped canonical proteins from mouse and rat to the corresponding ortholog human proteins, which were 
bioRxiv preprint doi: https://doi.org/10.1101/2021.12.20.473413; this version posted December 21, 2021. The copyright holder for this preprint (which was not certified by peer review) is the author/funder, who has granted bioRxiv a license to display the preprint in perpetuity. It is made available under aCC-BY-NC-ND 4.0 International license.

subsequently subjected to pathway-enrichment analysis using Reactome (Fig. 8). After

357 filtering out the disease and statistically insignificant pathways, there were 2,990 pathways

358 found in all the organs of mouse and 2,162 pathways in all the organs of rat. In mouse

359 samples, the largest number of pathways (367) were found in articular cartilage, and the

360 lowest number of pathways was from liver (44). We also observed that Neuronal System-

361 related pathways are predominantly present in the brain and eye, which is consistent with

362 expectations. In rat samples, brain included the largest number of pathways (387), while the

363 lowest number of pathways was found in tendon, with 117.

364
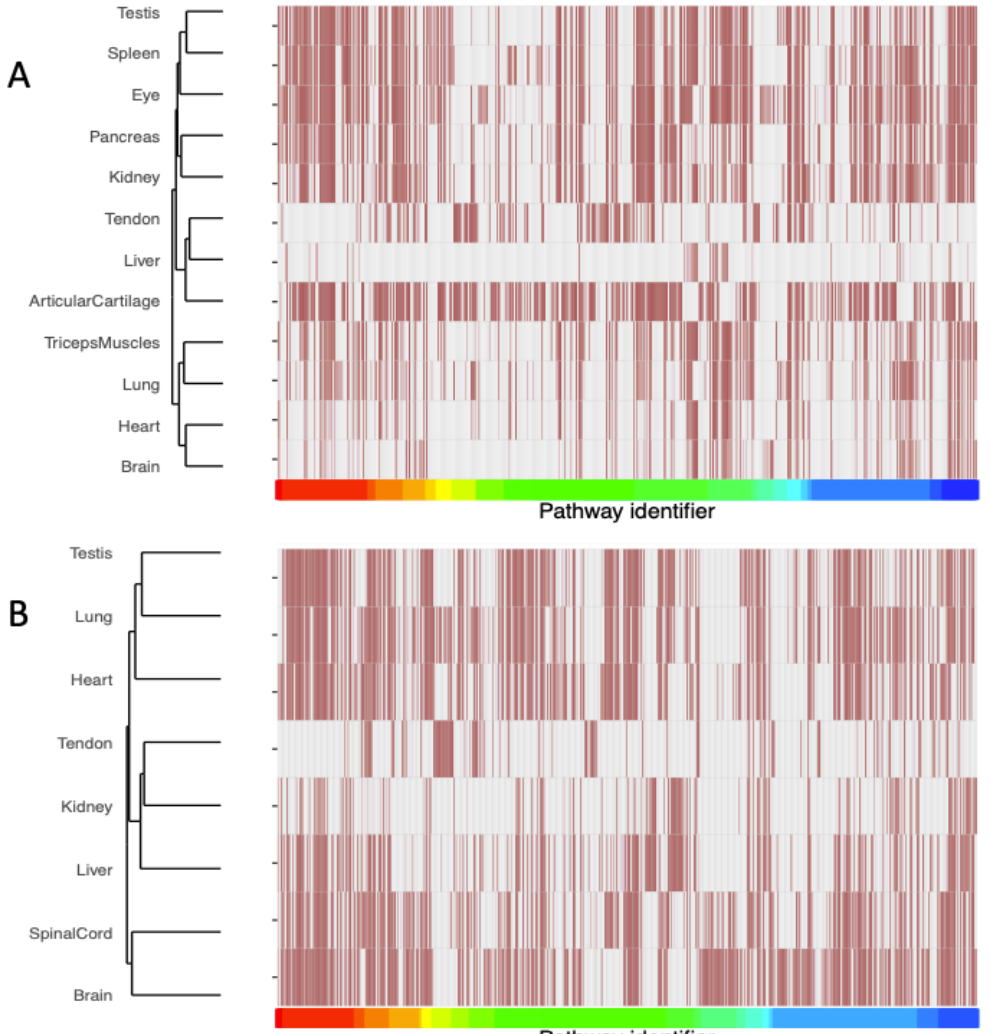

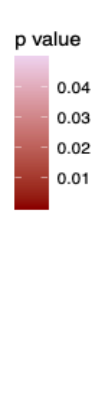

Pathway name
Autophagy
Cell Cycle
Cell-Cell communication
Cellular responses to stimuli
Chromatin organization

Developmental Biology

DNA Repair

DNA Replication

Extracellular matrix organization

Gene expression (Transcription)

Hemostasis

Immune System

Metabolism

Metabolism of proteins

Metabolism of RNA

Muscle contraction

Neuronal System

Organelle biogenesis and maintenance

Programmed Cell Death

- Protein localization

- Sensory Perception

- Signal Transduction

- Transport of small molecules

- Vesicle-mediated transport

366 Figure 8. Pathway analysis of the canonical proteins, showing the statistically significant

367 representative pathways ( $\mathrm{p}$-value $<0.05$ ) in (A) mouse and (B) rat organs. 


\section{Discussion}

371 We have previously reported two meta-analysis studies involving the reanalysis and

372 integration in Expression Atlas of public quantitative datasets coming from cell lines and

373 human tumour samples [14], and from human baseline tissues [15], respectively. In this

374 study, we reanalysed mouse and rat baseline proteomics datasets representing protein expression across 34 healthy tissues and 14 organs. We have used the same methodology as in the study involving baseline human tissues, which enabled a comparison of protein expression levels across the three species. Our main overall aim was to provide a systemwide baseline protein expression catalogue across various tissues and organs of mouse and rat and to offer a reference for future related studies.

381 We analysed each dataset separately using the same software (MaxQuant) and the same search protein sequence database. The disadvantage of this approach is that the False Discovery Rate (FDR) statistical thresholds are applied at a dataset level and not to all datasets together as a whole. However, as reported before [15], using a dataset per dataset analysis approach is in our view the only sustainable manner to reanalyse and integrate quantitative proteomics datasets, at least at present. As also reported in previous studies, one of the major bottlenecks was the curation of dataset metadata, consisting of mapping files to samples and biological conditions. Very recently, the MAGE-TAB-Proteomics format has

389 been developed and formalised to enable the reporting of the experimental design in

390 proteomics experience, including the relationship between samples and raw files, which is recorded in the SDRF-Proteomics section of the file [41]. Submission of the SDRF-

392 Proteomics files to PRIDE is now supported. The more well-annotated datasets in the public 393 domain, the easier data re-use activities will become. 
The generated baseline protein expression data can be used with different purposes such as the generation of protein co-expression networks and/or the inference of protein complexes.

397 For the latter application, expression data can be alone or potentially refining predictions

398 obtained using different methods such as the recently developed AlphaFold-based protein complexes predictions [42]. Mouse and rat are widely used species in the context of drug discovery, the latter especially, to undertake regulatory pre-clinical safety studies. Therefore,

401 it is important to know quantitative protein expression distribution in these species in different tissues [43] to assist in the selection of species for such studies and also for the interpretation of the final results.

In addition to the analyses reported, it would also be possible to perform correlation studies between gene and protein expression information. However, we did not find any relevant public datasets in the context of this manuscript where the same samples were analysed by both techniques, which is the optimal way to perform these studies. Future directions in analogous studies will involve: (i) additional baseline protein expression studies of other

410 species, including other model organisms or other species of economic importance; (ii) the

411 inclusion of differential datasets (e.g. using TMT and/or iTRAQ); and (iii) include relevant

412 proteomics expression data coming from the reanalysis of Data Independent Acquisition

413 (DIA) datasets [44].

415 As mentioned above, we performed a comparative analysis of baseline protein expression 416 across human, mouse and rat. It was possible to perform this analysis for six common organs 417 (brain, heart, kidney, liver, lung and testis). Ortholog expression across species is useful to 418 infer protein function across experimentally studied proteins. This is particularly useful as 419 evolutionarily closely related species are likely to conserve protein function. We could not 
420 find in the literature an analogous comparative study performed at the protein level.

421 However, protein expression from closely related orthologs across tissues or organs has been

422 compared at the transcriptomics level, providing a complete picture of gene expression. In

423 this context, many studies have compared gene-expression in mouse, rat and human

424 orthologues and found that orthologues had generally a highly correlated expression tissue

425 distribution profile in baseline conditions [45-49]. Gene expression levels among orthologs

426 were found to be highly similar in muscle and heart tissues, liver and nervous system and less

427 similar in epithelial cells, reproductive systems, bone and endocrine organs [47]. Studies have

428 also shown that variability of gene expression between homologous tissues/organs in closely

429 related species can be much lower than the variability between unrelated tissues within the

430 same organism $[45,46]$, in agreement with the results reported here at the protein level.

431

432 In conclusion we here present a meta-analysis study of public mouse and rat baseline

433 proteomics datasets from PRIDE. We demonstrate its feasibility, perform a comparative

434 analysis across the three species and show the main current challenges. Finally, the data is

435 made available via Expression Atlas. Whereas there are several analogous studies performed

436 at the gene expression level for mouse and rat tissues, this is the first of this kind at the

437 protein expression level. 


\section{Materials and Methods}

\subsection{Datasets}

As of May 2021, there were 2,060 mouse (Mus musculus) and 339 rat (Rattus norvegicus)

MS proteomics datasets publicly available in the PRIDE database

444 (https://www.ebi.ac.uk/pride/). Datasets were manually selected based on the selection

criteria described previously [15]. Briefly, we selected datasets where baseline expression

translational modifications; (ii) Thermo Fisher Scientific instruments such as LTQ Orbitrap,

Orbitrap Fusion and Q-Exactive, since they represent a large proportion of datasets in PRIDE deposited in PRIDE, which were discarded because they were not considered to be useful (data not shown). Overall, 14 mouse and 9 rat datasets were selected from all mouse and rat datasets for further analysis. Table 1 lists the selected datasets. The 23 datasets contained a total of 211 samples from 34 different tissues across 14 organs (meaning groups of related tissues, more details below), comprising 9 different mouse and 3 rat strains, respectively. The sample and experimental metadata were manually curated using the information provided in the respective publications or by contacting the original authors/submitters.

460 Annotare [50] was used for annotating the metadata and stored using the Investigation

461 Description Format (IDF) and Sample-Data Relationship Format (SDRF) file formats [41],

462 which are required for integration in Expression Atlas. An overview of the experimental

463 design including experimental factors, protocols, publication information and contact 
information are present in the IDF file, and the SDRF includes sample metadata describing the relationship between the various sample characteristics and the data files contained in the dataset.

\subsection{Proteomics raw data processing}

469 All datasets were analysed with MaxQuant (version 1.6.3.4) [51, 52] on a Linux highperformance computing cluster for peptide/protein identification and protein quantification. Input parameters for each dataset, such as MS1 and MS2 tolerances, digesting enzymes, fixed and variable modifications, were set as described in their respective publications, with two missed cleavage sites. The FDR at the PSM (peptide spectrum match) and protein levels were set to $1 \%$. The MaxQuant parameters were otherwise set to default values: the maximum number of modifications per peptide was 5 , the minimum peptide length was 7 , the maximum peptide mass was set to $4,600 \mathrm{Da}$, and for the matches between runs the minimum match time window was set to 0.7 seconds and the minimum retention time alignment window was set to 20 seconds. The MaxQuant parameter files are available for downloading from Expression Atlas. The Mus musculus UniProt Reference proteome release-2021_04 (including isoforms, 63,656 sequences) and Rattus norvegicus UniProt Reference proteome release-2021_04

481 (including isoforms, 31,562 sequences) were used as the target sequence databases for mouse and rat datasets, respectively. The built-in contaminant database within MaxQuant was used and a decoy database was generated by MaxQuant by reversing the input database sequences

484 after the respective enzymatic digestion. The datasets were run separately in multi-threaded mode.

\subsection{Post-processing}



protein groups labelled as potential contaminants, decoys and those with less than 2 PSMs intensity values to the total amount of signal in each MS run and converted to parts per

492 billion (ppb).

$$
p p b_{-} i B A Q_{i}=\left(i B A Q_{i} / \sum_{i=1}^{n} i B A Q_{i}\right) \times 1,000,000,000
$$

The 'majority protein identifiers' within each protein group were mapped to their Ensembl gene identifiers/annotations using the Bioconductor package 'mygene'. For downstream analysis only protein groups whose isoforms mapped to a single unique Ensembl gene ID were considered. Protein groups that mapped to more than one Ensembl gene ID are provided in Supplementary file 1. The protein intensity values from different protein groups with the same Ensembl gene ID were aggregated as median values. The parent genes to which the different protein groups were mapped to are equivalent to 'canonical proteins' in UniProt abundance is used to describe the protein abundance of the canonical protein throughout the manuscript.

\subsection{Integration into Expression Atlas}

506 The calculated canonical protein abundances (mapped to genes), together with the validated

507 SDRF files, summary files detailing the quality of post-processing and the input MaxQuant

508 parameter files (mqpar.xml) were integrated into Expression Atlas

509 (https://www.ebi.ac.uk/gxa/home) as proteomics baseline experiments (E-PROT identifiers are available in Table 1). 
513 To compare protein abundances, the normalised protein abundances (in ppb) from each group

514 of tissues in a dataset were converted into ranked bins. In this study, 'tissue' is defined as a

515 distinct functional or structural region within an 'organ'. For example, hippocampus,

516 cerebellum and cortex are defined as 'tissues' that are part of the brain (organ) and similarly

517 sinus node, left atria, left ventricle, right atria, right ventricle are defined as 'tissues' in heart

518 (organ). Protein abundances were transformed into bins by first grouping MS runs from each

519 tissue within a dataset as a batch. The normalised protein abundances (ppb) for each MS run

520 within a batch were sorted from lowest to highest abundance and ranked into 5 bins. Proteins

521 whose ppb abundances are ranked in the lowest bin (bin 1) represent lowest abundance and

522 correspondingly proteins within bin 5 are of highest abundance in their respective tissue.

523 When merging tissues into organs, median bin values were used.

524 Proteins that were detected in at least $50 \%$ of the samples were selected for PCA (Principal

525 Component Analysis) and was performed using R (The R Stats package) [53] using binned

526 abundance values. For generating heatmaps, a Pearson correlation coefficient (rp) for all

527 samples was calculated on pairwise complete observations of bin transformed values.

528 Missing values were marked as NA (not available). For each organ a median rp was

529 calculated from all pairwise rp values of their respective samples. Samples were

530 hierarchically clustered on columns and rows using Euclidean distances.

\section{4.6. Organ-specific expression profile analysis}

532 For comparison across organs, the tissues were aggregated into organs and their median bin

533 values were considered. As described previously [15] the classification scheme done by

534 Uhlén et al. [17] was modified to classify the proteins into one of the three categories: (1)

535 "Organ-enriched": present in one unique organ with bin values 2-fold higher than the mean

536 bin value across all organs; (2) “Group enriched": present in at least 7 organs in mouse or in 
at least 4 organs in rat, with bin values 2 -fold higher than the mean bin value across all organs; and (3) "Mixed": the remaining canonical proteins that are not part of the above two categories.

541 Enriched gene ontology (GO) terms analysis was carried out through over-representation test

542 described previously [15], it was combined with "Organ-enriched" and "Group enriched"

543 mapped gene lists for each organ. In addition, Reactome [54] pathway analysis was

544 performed using mapped gene lists and running pathway-topology and over-representation 545 analysis, as reported previously [15].

\subsection{Comparison of protein expression across species}

547 The g:Orth Orthology search function in the g:Profiler suite of programs [55] was used for translating gene identifiers between organisms. Since a custom list of gene identifiers could not be used as the background search set, the mouse and rat genes were first mapped against the background Ensembl database. The resulting list of mouse and rat genes mapped to human orthologs were then filtered so that they only included parent gene identifiers of the protein groups from mouse and rat organs identified in this study and the parent genes of human organs described in our previous study (Supplementary file 2 in [15]), respectively.

The orthologs were grouped into various categories denoting the resulting mapping between identifiers: “one-to-one”, “one-to-many”, "many-to-one”, "many-to-many”, and "no mappings" between gene identifiers. Only "one-to-one" mapped ortholog identifiers were used to compare protein intensities between mouse, rat and human organs. The normalised ppb protein abundances of the one-to-one mapped orthologues in 6 organs (brain, heart, 
the pairwise correlation of protein abundances. The linear regression was calculated using the

562 linear fit ' $1 \mathrm{~m}$ ' method in R.

563

564 Data availability

565 Expression Atlas E-PROT identifiers and PRIDE original dataset identifiers are included in 566 Table 1.

\section{Acknowledgements}

568 First of all, we would like to thank all data submitters who made their datasets available via

569 PRIDE and ProteomeXchange. We would also like to thank Andrew Leach and the rest of the

570 team involved in the Open Targets target safety project, for helpful discussions. This work

571 has been funded by Open Targets (project OTAR-02-068), Wellcome Trust [grant number 208391/Z/17/Z], BBSRC [BB/T019670/1 and BB/T019557/1] and EMBL core funding.

\section{Authors' contributions}

574 SW, DGS, AP, DJK selected and curated the datasets. SW, AP, DGS performed analyses. AC 575 and ARJ helped in the interpretation of results and designed approach for data normalisation.

$576 \mathrm{NG}, \mathrm{SF}, \mathrm{PM}$, and IP helped in the integration of the results into Expression Atlas. SW, AP, 577 DGS, JAV wrote the manuscript. JAV, ARJ and IP obtained the funding for performing the 578 study. All authors have read and approved the manuscript.

580 Supporting information

581 Supplementary file 1: Protein groups from all datasets that are mapped to more than one

582 Ensembl Gene ID. 
583 Supplementary file 2: Median protein abundances (in $\mathrm{ppb}$ ) for each protein group across

584 various tissue samples in each organ.

585 Supplementary file 3: Median binned protein abundances across various tissue samples in

586 each organ of mouse and rat.

587 Supplementary file 4: Organ distribution of canonical proteins in mouse and rat.

588 Supplementary file 5: Gene Ontology enrichment analysis of 'organ-enriched' and 'group-

589 enriched' proteins.

590 Supplementary file 6: Correlation of protein expression between organs within each

591 organism.

592 Supplementary file 7: Binned protein abundances of one-to-one mapped orthologs across all

593 organs studied.

594 Supplementary file 8: Figure illustrating binned protein abundances of all one-to-one

595 mapped orthologs across six common organs in mouse, rat and human.

\section{Abbreviations}

598 DDA: Data Dependent Acquisition

599 DIA: Data Independent Acquisition

600 FOT: Fraction of Total

601 GO: Gene Ontology

602 iBAQ: intensity-based absolute quantification

603 iTRAQ: Isobaric tag for relative and absolute quantitation

604 IDF: Investigation Description Format 
605 MS: Mass Spectrometry

606 ppb: Parts per billion

607 PCA: Principal Component Analysis

608 rp: Pearson correlation coefficient

609 SDRF: Sample and Data Relationship Format

610 TMT: Tandem Mass Tagging 
611

612

613

614

615

616

617

618

619

620

621

622

623

624

625

626

627

628

629

630

631

632

633

634

635

636

637

638

639

640

641

642

643

644

645

646

647

648

649

650

651

652

653

654

655

656

657

658

659

660

\section{References}

1. Aebersold R, Mann M. Mass-spectrometric exploration of proteome structure and function. Nature. 2016;537(7620):347-55. Epub 2016/09/16. doi: 10.1038/nature19949. PubMed PMID: 27629641.

2. Perez-Riverol Y, Csordas A, Bai J, Bernal-Llinares M, Hewapathirana S, Kundu DJ, et al. The PRIDE database and related tools and resources in 2019: improving support for quantification data. Nucleic Acids Res. 2019;47(D1):D442-D50. Epub 2018/11/06. doi: 10.1093/nar/gky1106. PubMed PMID: 30395289; PubMed Central PMCID: PMCPMC6323896.

3. Vizcaino JA, Deutsch EW, Wang R, Csordas A, Reisinger F, Rios D, et al. ProteomeXchange provides globally coordinated proteomics data submission and dissemination. Nat Biotechnol. 2014;32(3):223-6. Epub 2014/04/15. doi: 10.1038/nbt.2839. PubMed PMID: 24727771; PubMed Central PMCID: PMCPMC3986813.

4. Martens L, Vizcaino JA. A Golden Age for Working with Public Proteomics Data. Trends Biochem Sci. 2017;42(5):333-41. Epub 2017/01/26. doi: 10.1016/j.tibs.2017.01.001. PubMed PMID: 28118949; PubMed Central PMCID: PMCPMC5414595.

5. Romanov N, Kuhn M, Aebersold R, Ori A, Beck M, Bork P. Disentangling Genetic and Environmental Effects on the Proteotypes of Individuals. Cell. 2019;177(5):1308-18 e10. Epub 2019/04/30. doi: 10.1016/j.cell.2019.03.015. PubMed PMID: 31031010; PubMed Central PMCID: PMCPMC6988111.

6. Skinnider MA, Foster LJ. Meta-analysis defines principles for the design and analysis of co-fractionation mass spectrometry experiments. Nat Methods. 2021;18(7):806-15. Epub 2021/07/03. doi: 10.1038/s41592-021-01194-4. PubMed PMID: 34211188.

7. Ochoa D, Jarnuczak AF, Vieitez C, Gehre M, Soucheray M, Mateus A, et al. The functional landscape of the human phosphoproteome. Nat Biotechnol. 2020;38(3):365-73. Epub 2019/12/11. doi: 10.1038/s41587-019-0344-3. PubMed PMID: 31819260; PubMed Central PMCID: PMCPMC7100915.

8. Vaudel M, Verheggen K, Csordas A, Raeder H, Berven FS, Martens L, et al. Exploring the potential of public proteomics data. Proteomics. 2016;16(2):214-25. Epub 2015/10/10. doi: 10.1002/pmic.201500295. PubMed PMID: 26449181; PubMed Central PMCID: PMCPMC4738454.

9. Kumar D, Yadav AK, Jia X, Mulvenna J, Dash D. Integrated TranscriptomicProteomic Analysis Using a Proteogenomic Workflow Refines Rat Genome Annotation. Mol Cell Proteomics. 2016;15(1):329-39. Epub 2015/11/13. doi: 10.1074/mcp.M114.047126. PubMed PMID: 26560066; PubMed Central PMCID: PMCPMC4762527.

10. Brunet MA, Brunelle M, Lucier JF, Delcourt V, Levesque M, Grenier F, et al. OpenProt: a more comprehensive guide to explore eukaryotic coding potential and 
661

662

663

664

665

666

667

668

669

670

671

672

673

674

675

676

677

678

679

680

681

682

683

684

685

686

687

688

689

690

691

692

693

694

695

696

697

698

699

700

proteomes. Nucleic Acids Res. 2019;47(D1):D403-D10. Epub 2018/10/10. doi: 10.1093/nar/gky936. PubMed PMID: 30299502; PubMed Central PMCID: PMCPMC6323990.

11. Levitsky LI, Kliuchnikova AA, Kuznetsova KG, Karpov DS, Ivanov MV, Pyatnitskiy MA, et al. Adenosine-to-Inosine RNA Editing in Mouse and Human Brain Proteomes. Proteomics. 2019;19(23):e1900195. Epub 2019/10/03. doi: 10.1002/pmic.201900195. PubMed PMID: 31576663.

12. Li H, Zhou R, Xu S, Chen X, Hong Y, Lu Q, et al. Improving Gene Annotation of the Peanut Genome by Integrated Proteogenomics Workflow. J Proteome Res. 2020;19(6):2226-35. Epub 2020/05/06. doi: 10.1021/acs.jproteome.9b00723. PubMed PMID: 32367721.

13. Moreno P, Fexova S, George N, Manning JR, Miao Z, Mohammed S, et al. Expression Atlas update: gene and protein expression in multiple species. Nucleic Acids Res. 2021. Epub 2021/12/02. doi: 10.1093/nar/gkab1030. PubMed PMID: 34850121.

14. Jarnuczak AF, Najgebauer H, Barzine M, Kundu DJ, Ghavidel F, Perez-Riverol Y, et al. An integrated landscape of protein expression in human cancer. Sci Data. 2021;8(1):115. Epub 2021/04/25. doi: 10.1038/s41597-021-00890-2. PubMed PMID: 33893311; PubMed Central PMCID: PMCPMC8065022.

15. Prakash A, García-Seisdedos D, Wang S, Kundu DJ, Collins A, George N, et al. An integrated view of baseline protein expression in human tissues. bioRxiv.

2021:2021.09.10.459811. doi: 10.1101/2021.09.10.459811.

16. Samaras P, Schmidt T, Frejno M, Gessulat S, Reinecke M, Jarzab A, et al. ProteomicsDB: a multi-omics and multi-organism resource for life science research. Nucleic Acids Res. 2020;48(D1):D1153-D63. Epub 2019/10/31. doi: 10.1093/nar/gkz974. PubMed PMID: 31665479; PubMed Central PMCID: PMCPMC7145565.

17. Uhlen M, Fagerberg L, Hallstrom BM, Lindskog C, Oksvold P, Mardinoglu A, et al. Proteomics. Tissue-based map of the human proteome. Science. 2015;347(6220):1260419. Epub 2015/01/24. doi: 10.1126/science.1260419. PubMed PMID: 25613900.

18. Azimifar SB, Nagaraj N, Cox J, Mann M. Cell-type-resolved quantitative proteomics of murine liver. Cell Metab. 2014;20(6):1076-87. Epub 2014/12/04. doi: 10.1016/j.cmet.2014.11.002. PubMed PMID: 25470552.

19. Deshmukh AS, Murgia M, Nagaraj N, Treebak JT, Cox J, Mann M. Deep proteomics of mouse skeletal muscle enables quantitation of protein isoforms, metabolic pathways, and transcription factors. Mol Cell Proteomics. 2015;14(4):841-53. Epub 2015/01/27. doi: 10.1074/mcp.M114.044222. PubMed PMID: 25616865; PubMed Central PMCID: PMCPMC4390264.

20. Meierhofer D, Halbach M, Sen NE, Gispert S, Auburger G. Ataxin-2 (Atxn2)-KnockOut Mice Show Branched Chain Amino Acids and Fatty Acids Pathway Alterations. Mol Cell Proteomics. 2016;15(5):1728-39. Epub 2016/02/07. doi: 10.1074/mcp.M115.056770. PubMed PMID: 26850065; PubMed Central PMCID: PMCPMC4858951. 

differences in tendon structure and function. J Orthop Res. 2017;35(10):2117-26. Epub 2017/01/11. doi: 10.1002/jor.23516. PubMed PMID: 28071813; PubMed Central PMCID: PMCPMC5503813.

22. Duda P, Wojcicka O, Wisniewski JR, Rakus D. Global quantitative TPA-based proteomics of mouse brain structures reveals significant alterations in expression of proteins involved in neuronal plasticity during aging. Aging (Albany NY). 2018;10(7):1682-97. Epub 2018/07/22. doi: 10.18632/aging.101501. PubMed PMID: 30026405; PubMed Central PMCID: PMCPMC6075443.

23. Harman JC, Guidry JJ, Gidday JM. Comprehensive characterization of the adult ND4 Swiss Webster mouse retina: Using discovery-based mass spectrometry to decipher the total proteome and phosphoproteome. Mol Vis. 2018;24:875-89. Epub 2019/02/05. PubMed PMID: 30713425; PubMed Central PMCID: PMCPMC6334985.

24. Angelidis I, Simon LM, Fernandez IE, Strunz M, Mayr CH, Greiffo FR, et al. An atlas of the aging lung mapped by single cell transcriptomics and deep tissue proteomics. Nat Commun. 2019;10(1):963. Epub 2019/03/01. doi: 10.1038/s41467-019-08831-9. PubMed PMID: 30814501; PubMed Central PMCID: PMCPMC6393476.

25. Zhao Y, Wilmarth PA, Cheng C, Limi S, Fowler VM, Zheng D, et al. Proteometranscriptome analysis and proteome remodeling in mouse lens epithelium and fibers. Exp Eye Res. 2019;179:32-46. Epub 2018/10/26. doi: 10.1016/j.exer.2018.10.011. PubMed PMID: 30359574; PubMed Central PMCID: PMCPMC6360118.

26. Huttlin EL, Jedrychowski MP, Elias JE, Goswami T, Rad R, Beausoleil SA, et al. A tissue-specific atlas of mouse protein phosphorylation and expression. Cell. 2010;143(7):1174-89. Epub 2010/12/25. doi: 10.1016/j.cell.2010.12.001. PubMed PMID: 21183079.

27. Linscheid N, Santos A, Poulsen PC, Mills RW, Calloe K, Leurs U, et al. Quantitative proteome comparison of human hearts with those of model organisms. PLoS Biol. 2021;19(4):e3001144. Epub 2021/04/20. doi: 10.1371/journal.pbio.3001144. PubMed PMID: 33872299; PubMed Central PMCID: PMCPMC8084454.

28. Dudek M, Angelucci C, Pathiranage D, Wang P, Mallikarjun V, Lawless C, et al. Circadian time series proteomics reveals daily dynamics in cartilage physiology. 10.1016/j.joca.2021.02.008. PubMed PMID: 33610821; PubMed Central PMCID: PMCPMC8113022.

29. Schroeder S, Hofer SJ, Zimmermann A, Pechlaner R, Dammbrueck C, Pendl T, et al. Dietary spermidine improves cognitive function. Cell Rep. 2021;35(2):108985. Epub 2021/04/15. doi: 10.1016/j.celrep.2021.108985. PubMed PMID: 33852843.

30. Bundy JL, Vied C, Nowakowski RS. Sex differences in the molecular signature of the developing mouse hippocampus. BMC Genomics. 2017;18(1):237. Epub 2017/03/18. doi: 

PMCPMC5356301.

31. Linscheid N, Logantha S, Poulsen PC, Zhang S, Schrolkamp M, Egerod KL, et al. Quantitative proteomics and single-nucleus transcriptomics of the sinus node elucidates the foundation of cardiac pacemaking. Nat Commun. 2019;10(1):2889. Epub 2019/06/30. doi: 10.1038/s41467-019-10709-9. PubMed PMID: 31253831; PubMed Central PMCID: PMCPMC6599035.

32. Alugubelly N, Mohammed AN, Edelmann MJ, Nanduri B, Sayed M, Park JW, et al. Adolescent rat social play: Amygdalar proteomic and transcriptomic data. Data Brief. 2019;27:104589. Epub 2019/11/02. doi: 10.1016/j.dib.2019.104589. PubMed PMID: 31673590; PubMed Central PMCID: PMCPMC6817652.

33. Roffia V, De Palma A, Lonati C, Di Silvestre D, Rossi R, Mantero M, et al. Proteome Investigation of Rat Lungs subjected to Ex Vivo Perfusion (EVLP). Molecules. 2018;23(12). Epub 2018/11/24. doi: 10.3390/molecules23123061. PubMed PMID: 30467300; PubMed Central PMCID: PMCPMC6321151.

34. Bernier M, Harney D, Koay YC, Diaz A, Singh A, Wahl D, et al. Elucidating the mechanisms by which disulfiram protects against obesity and metabolic syndrome. NPJ Aging Mech Dis. 2020;6:8. Epub 2020/07/28. doi: 10.1038/s41514-020-0046-6. PubMed PMID: 32714562; PubMed Central PMCID: PMCPMC7374720.

35. Huang Q, Luo L, Alamdar A, Zhang J, Liu L, Tian M, et al. Integrated proteomics and metabolomics analysis of rat testis: Mechanism of arsenic-induced male reproductive toxicity. Sci Rep. 2016;6:32518. Epub 2016/09/03. doi: 10.1038/srep32518. PubMed PMID: 27585557; PubMed Central PMCID: PMCPMC5009432.

36. Kaushik G, Spenlehauer A, Sessions AO, Trujillo AS, Fuhrmann A, Fu Z, et al. Vinculin network-mediated cytoskeletal remodeling regulates contractile function in the aging heart. Sci Transl Med. 2015;7(292):292ra99. Epub 2015/06/19. doi: 10.1126/scitranslmed.aaa5843. PubMed PMID: 26084806; PubMed Central PMCID: PMCPMC4507505.

37. Vileigas DF, Harman VM, Freire PP, Marciano CLC, Sant'Ana PG, de Souza SLB, et al. Landscape of heart proteome changes in a diet-induced obesity model. Sci Rep. 2019;9(1):18050. Epub 2019/12/04. doi: 10.1038/s41598-019-54522-2. PubMed PMID: 31792287; PubMed Central PMCID: PMCPMC6888820. 10.1681/ASN.2020010071. PubMed PMID: 32358040; PubMed Central PMCID: PMCPMC7269347.

39. Devaux S, Cizkova D, Quanico J, Franck J, Nataf S, Pays L, et al. Proteomic Analysis of the Spatio-temporal Based Molecular Kinetics of Acute Spinal Cord Injury Identifies a Time- and Segment-specific Window for Effective Tissue Repair. Mol Cell Proteomics. 2016;15(8):2641-70. Epub 2016/06/03. doi: 10.1074/mcp.M1 15.057794. PubMed PMID: 27250205; PubMed Central PMCID: PMCPMC4974342. 
810

811

812

813

814

815

816

817

818

819

820

821

822

823

824

825

826

827

828

829

830

831

832

833

834

835

836

837

838

839

840

841

842

843

844

845

846

847

848

849

850

851

852

853

854

855

856

857

858
40. Choi H, Simpson D, Wang D, Prescott M, Pitsillides AA, Dudhia J, et al. Heterogeneity of proteome dynamics between connective tissue phases of adult tendon. Elife. 2020;9. Epub 2020/05/13. doi: 10.7554/eLife.55262. PubMed PMID: 32393437; PubMed Central PMCID: PMCPMC7217697.

41. Dai C, Fullgrabe A, Pfeuffer J, Solovyeva EM, Deng J, Moreno P, et al. A proteomics sample metadata representation for multiomics integration and big data analysis. Nat Commun. 2021;12(1):5854. Epub 2021/10/08. doi: 10.1038/s41467-021-26111-3. PubMed PMID: 34615866; PubMed Central PMCID: PMCPMC8494749.

42. Evans R, O’Neill M, Pritzel A, Antropova N, Senior A, Green T, et al. Protein complex prediction with AlphaFold-Multimer. bioRxiv. 2021:2021.10.04.463034. doi: 10.1101/2021.10.04.463034.

43. Bregman CL, Adler RR, Morton DG, Regan KS, Yano BL, Society of Toxicologic P. Recommended tissue list for histopathologic examination in repeat-dose toxicity and carcinogenicity studies: a proposal of the Society of Toxicologic Pathology (STP). Toxicol Pathol. 2003;31(2):252-3. Epub 2003/04/17. doi: 10.1080/01926230390183751. PubMed PMID: 12696587.

44. Walzer M, García-Seisdedos D, Prakash A, Brack P, Crowther P, Graham RL, et al. Implementing the re-use of public DIA proteomics datasets: from the PRIDE database to Expression Atlas. bioRxiv. 2021:2021.06.08.447493. doi: 10.1101/2021.06.08.447493.

45. Sollner JF, Leparc G, Hildebrandt T, Klein H, Thomas L, Stupka E, et al. An RNASeq atlas of gene expression in mouse and rat normal tissues. Sci Data. 2017;4:170185. Epub 2017/12/13. doi: 10.1038/sdata.2017.185. PubMed PMID: 29231921; PubMed Central PMCID: PMCPMC5726313.

46. Sudmant PH, Alexis MS, Burge CB. Meta-analysis of RNA-seq expression data across species, tissues and studies. Genome Biol. 2015;16:287. Epub 2015/12/24. doi: 10.1186/s13059-015-0853-4. PubMed PMID: 26694591; PubMed Central PMCID: PMCPMC4699362.

47. Zheng-Bradley X, Rung J, Parkinson H, Brazma A. Large scale comparison of global gene expression patterns in human and mouse. Genome Biol. 2010;11(12):R124. Epub 2010/12/25. doi: 10.1186/gb-2010-11-12-r124. PubMed PMID: 21182765; PubMed Central PMCID: PMCPMC3046484.

48. Liao BY, Zhang J. Evolutionary conservation of expression profiles between human and mouse orthologous genes. Mol Biol Evol. 2006;23(3):530-40. Epub 2005/11/11. doi: 10.1093/molbev/msj054. PubMed PMID: 16280543.

49. Prasad A, Kumar SS, Dessimoz C, Bleuler S, Laule O, Hruz T, et al. Global regulatory architecture of human, mouse and rat tissue transcriptomes. BMC Genomics. 2013;14:716. Epub 2013/10/22. doi: 10.1186/1471-2164-14-716. PubMed PMID: 24138449; PubMed Central PMCID: PMCPMC4008137. 
bioRxiv preprint doi: https://doi.org/10.1101/2021.12.20.473413; this version posted December 21, 2021. The copyright holder for this preprint (which was not certified by peer review) is the author/funder, who has granted bioRxiv a license to display the preprint in perpetuity. It is made available under aCC-BY-NC-ND 4.0 International license.

50. Athar A, Fullgrabe A, George N, Iqbal H, Huerta L, Ali A, et al. ArrayExpress update - from bulk to single-cell expression data. Nucleic Acids Res. 2019;47(D1):D711-D5. Epub 2018/10/26. doi: 10.1093/nar/gky964. PubMed PMID: 30357387; PubMed Central PMCID: PMCPMC6323929.

51. Cox J, Mann M. MaxQuant enables high peptide identification rates, individualized p.p.b.-range mass accuracies and proteome-wide protein quantification. Nat Biotechnol. 2008;26(12):1367-72. Epub 2008/11/26. doi: 10.1038/nbt.1511. PubMed PMID: 19029910 .

52. Tyanova S, Temu T, Cox J. The MaxQuant computational platform for mass spectrometry-based shotgun proteomics. Nat Protoc. 2016;11(12):2301-19. Epub 2016/11/04. doi: 10.1038/nprot.2016.136. PubMed PMID: 27809316.

53. Team RC. R: A language and environment for statistical computing. R

Foundation for Statistical Computing, Vienna, Austria. ISBN 3-900051-07-0, URL http://wwwR-projectorg/. 2013.

54. Wu G, Haw R. Functional Interaction Network Construction and Analysis for Disease Discovery. Methods Mol Biol. 2017;1558:235-53. Epub 2017/02/06. doi: 10.1007/978-14939-6783-4_11. PubMed PMID: 28150241.

55. Raudvere U, Kolberg L, Kuzmin I, Arak T, Adler P, Peterson H, et al. g:Profiler: a web server for functional enrichment analysis and conversions of gene lists (2019 update). Nucleic Acids Res. 2019;47(W1):W191-W8. Epub 2019/05/09. doi: 10.1093/nar/gkz369. PubMed PMID: 31066453; PubMed Central PMCID: PMCPMC6602461. 
bioRxiv preprint doi: https://doi.org/10.1101/2021.12.20.473413; this version posted December 21, 2021. The copyright holder for this

preprint (which was not certified by peer review) is the author/funder, who has granted bioRxiv a license to display the preprint in perpetuity. It is made available under aCC-BY-NC-ND 4.0 International license.

885 


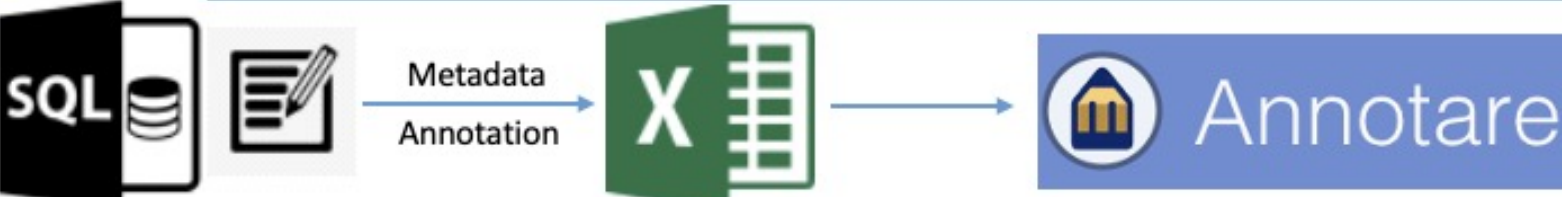

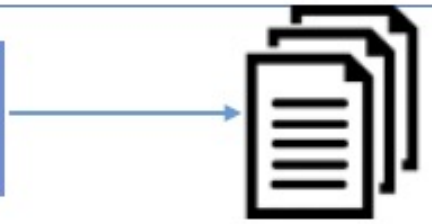

Curation

datasets selection

Experimental design templates

IDF \& SDRF

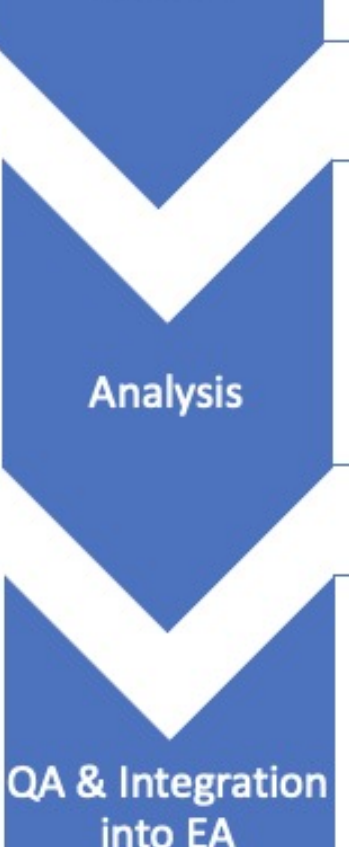

into EA

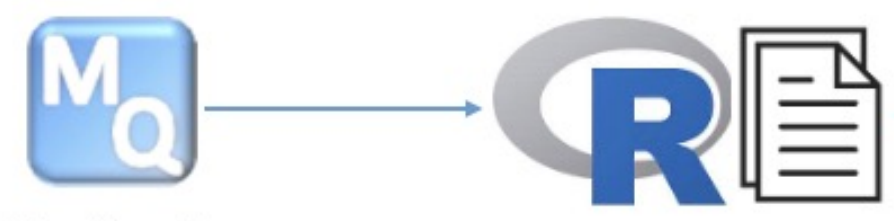

MaxQuant

Post-processing

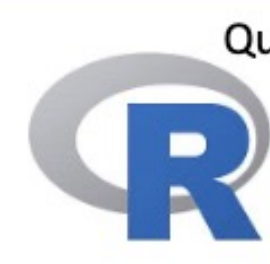

Quality control summary

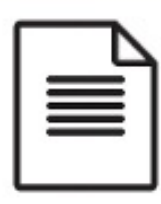

Post-process summary
Normalized protein abundances

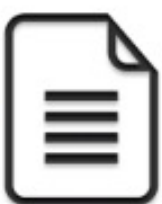

Normalized protein abundances




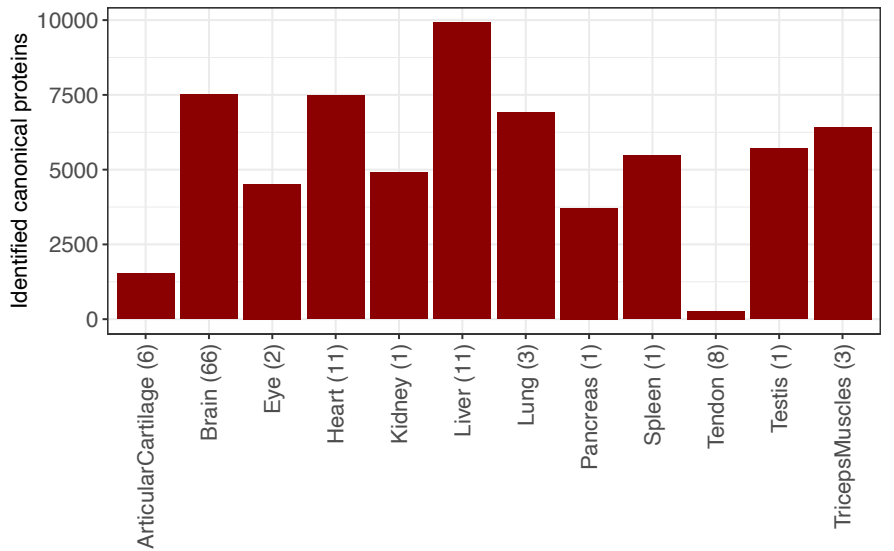

B

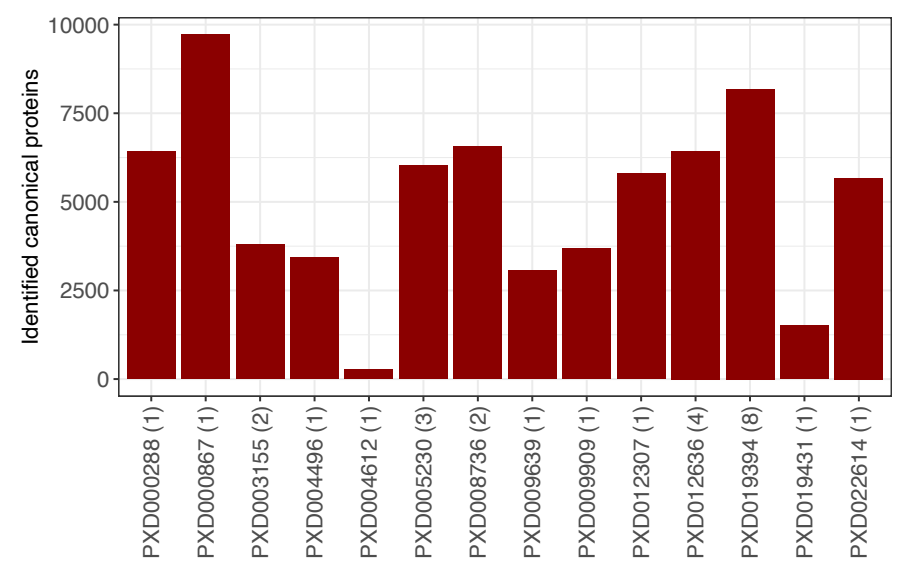

C

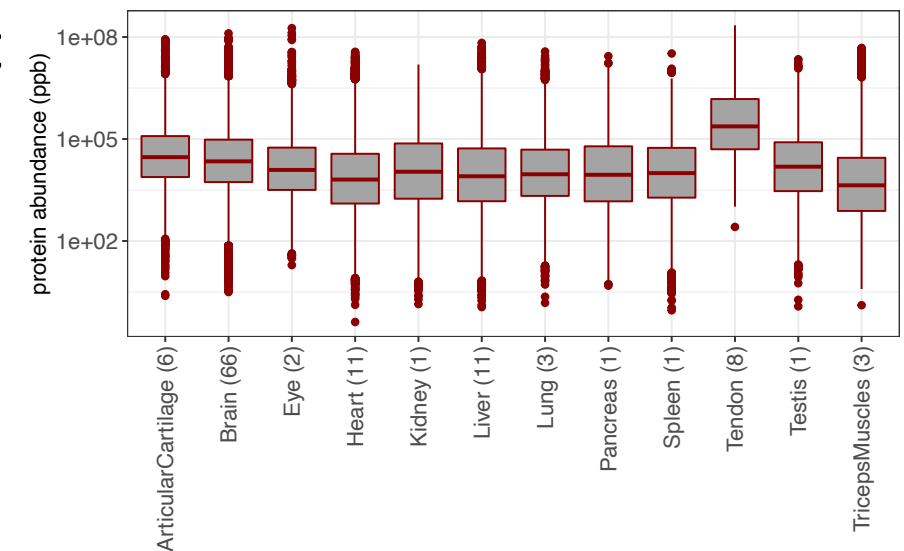

E
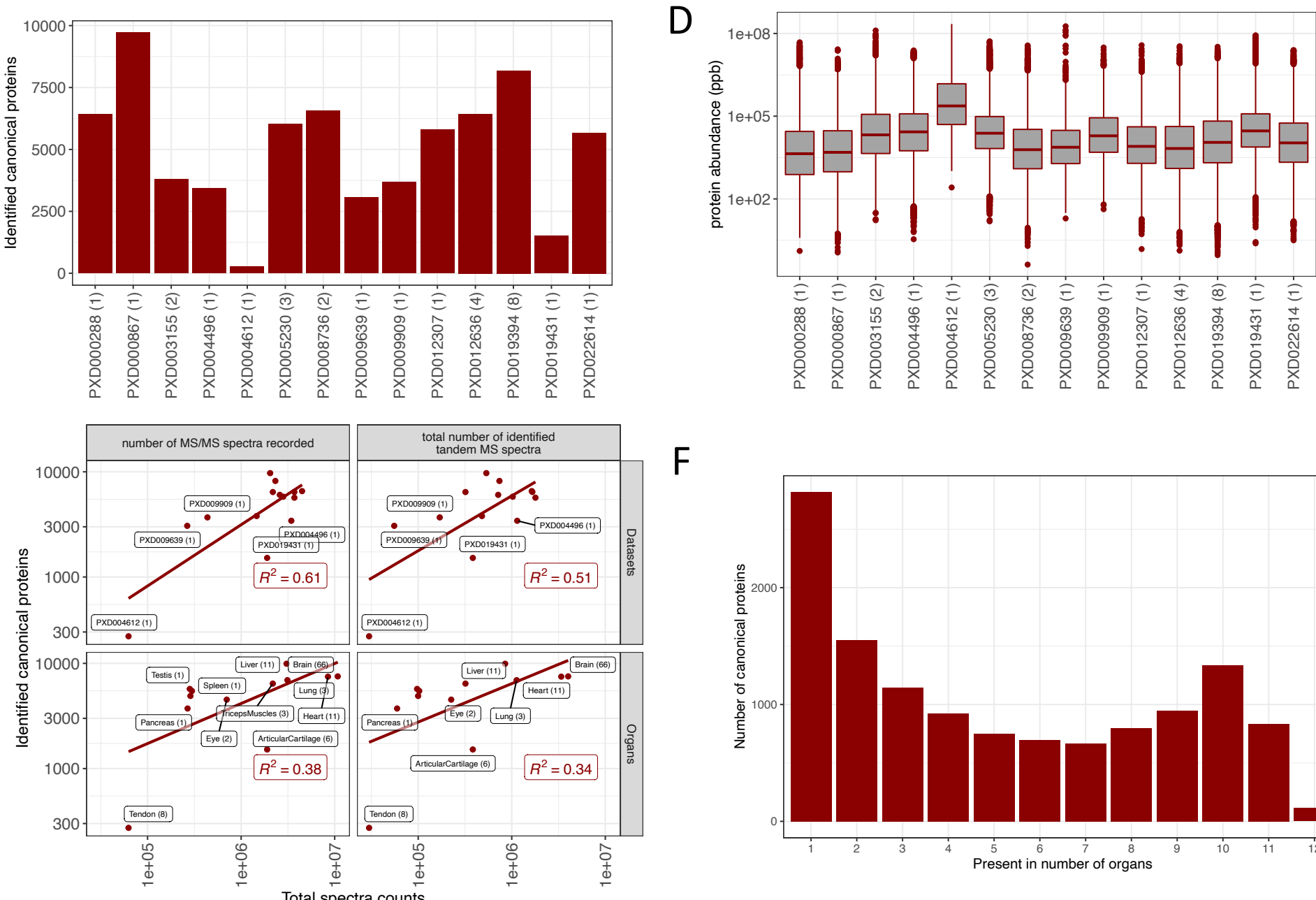

F

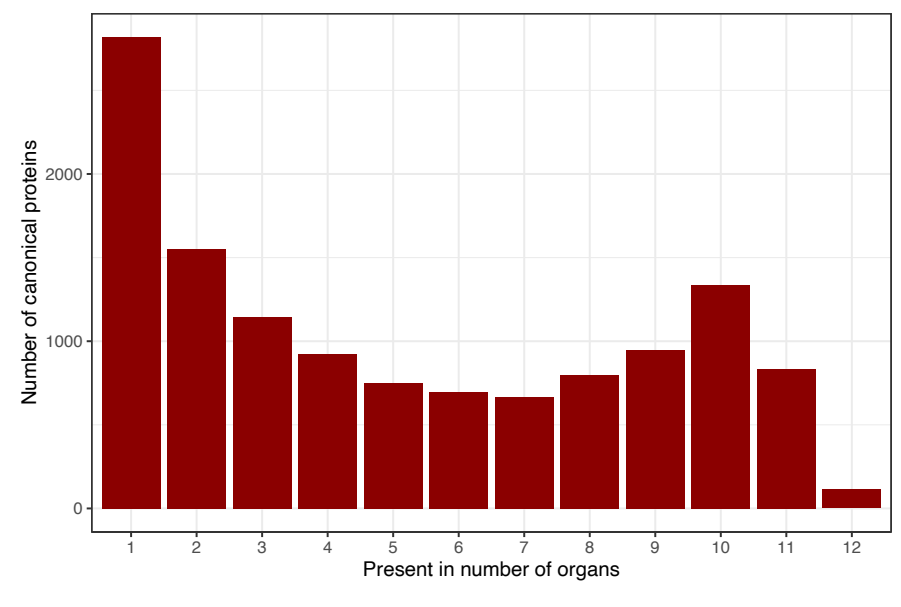

Total spectra counts 
A

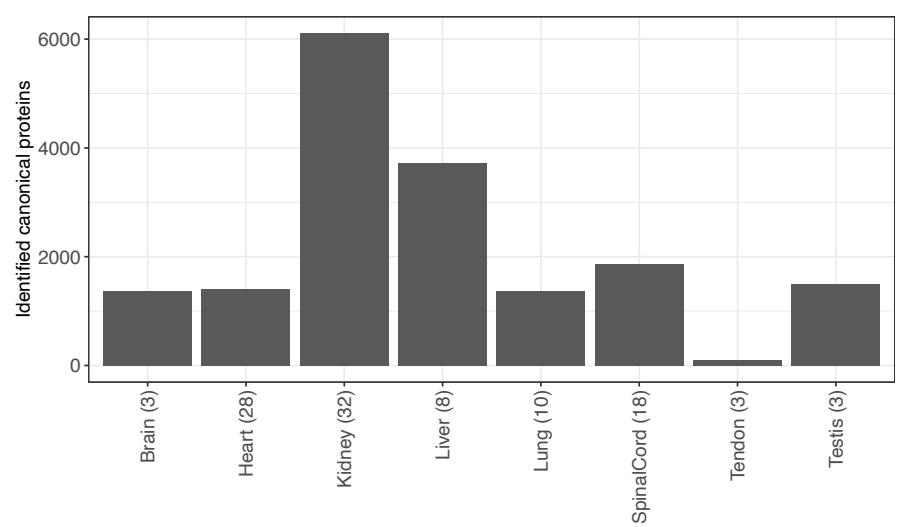

B

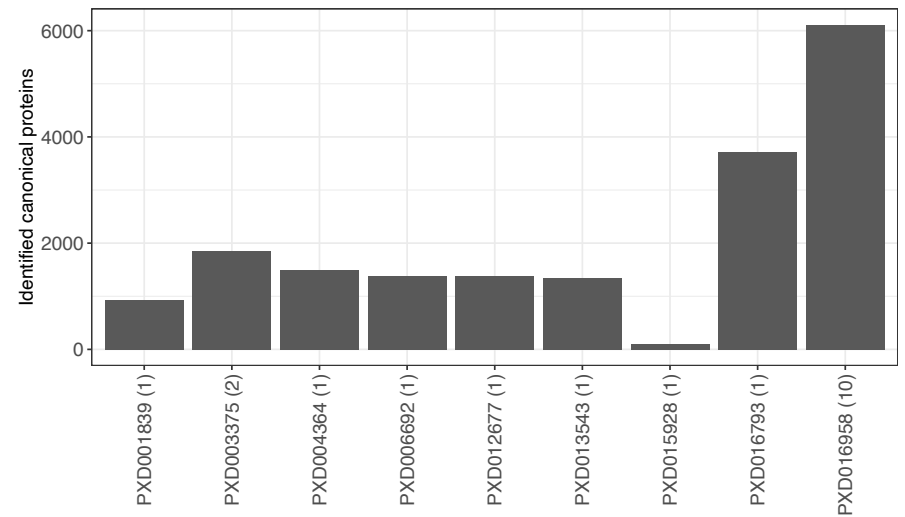

$E$

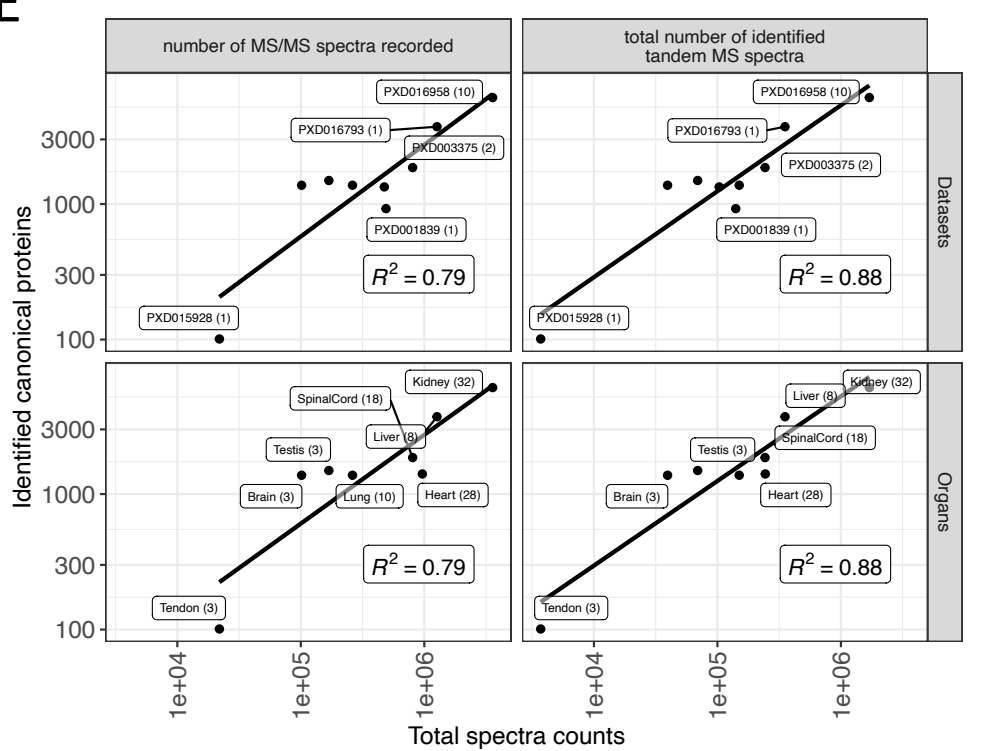

C

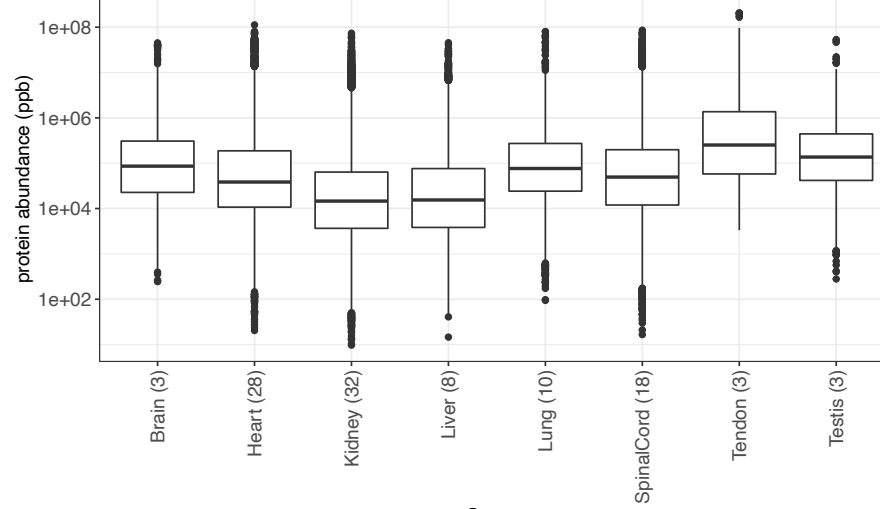

D

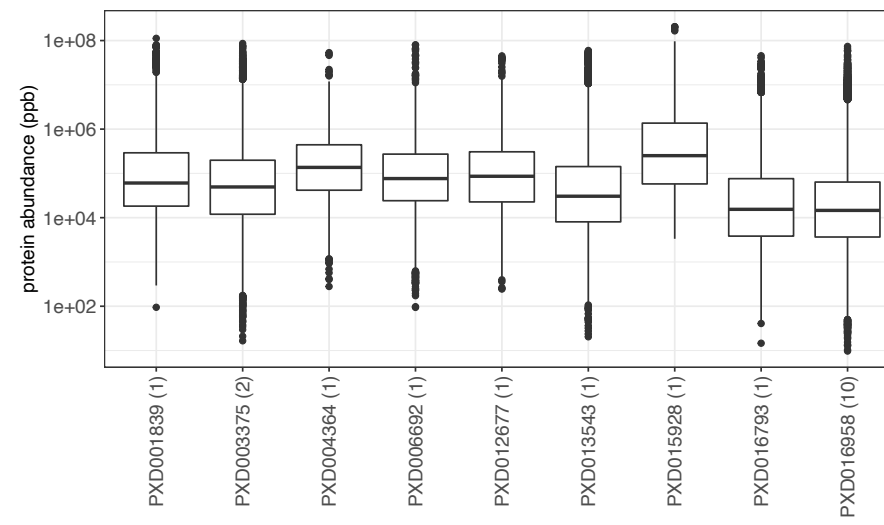

F

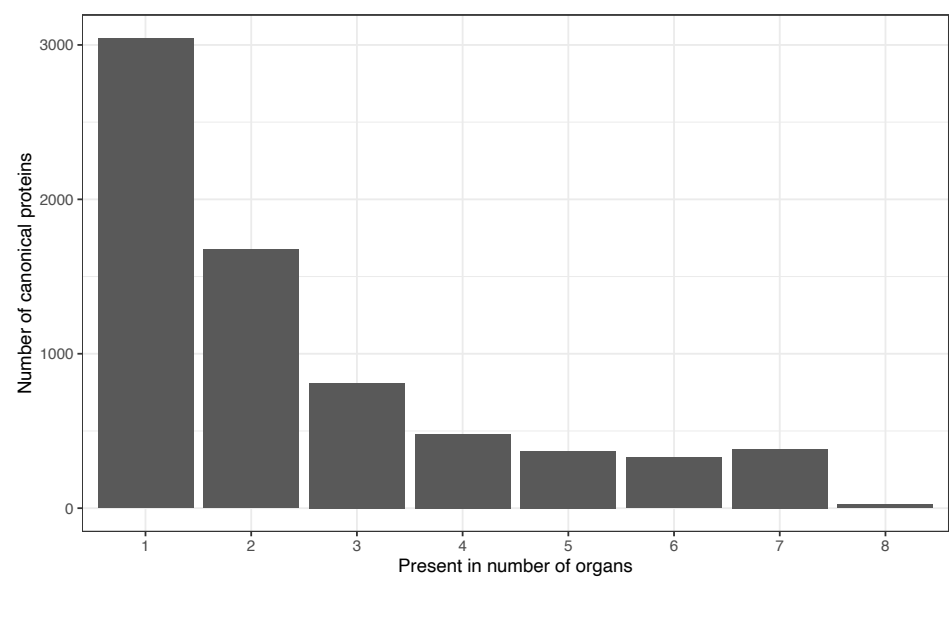




\section{A}

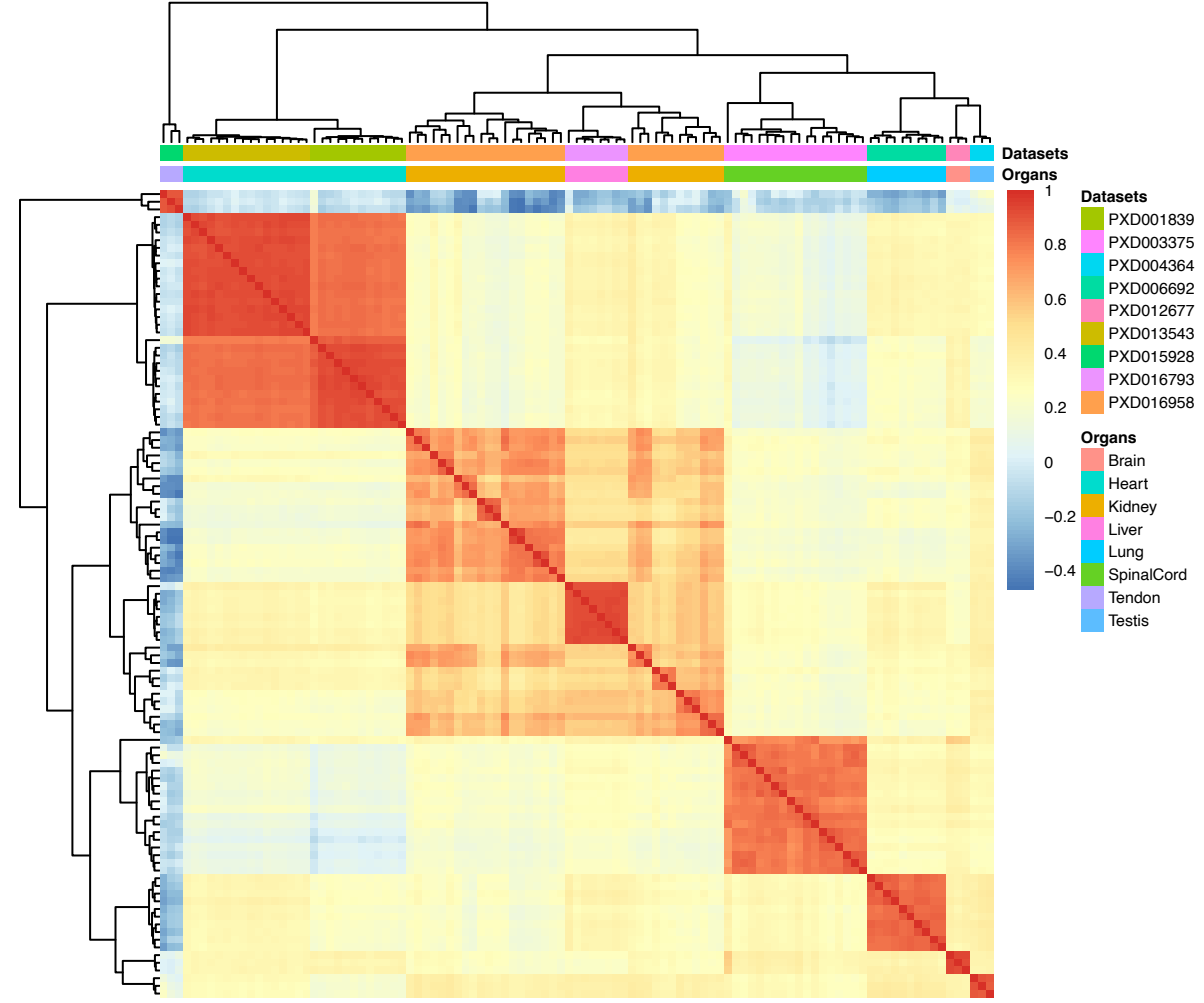

B

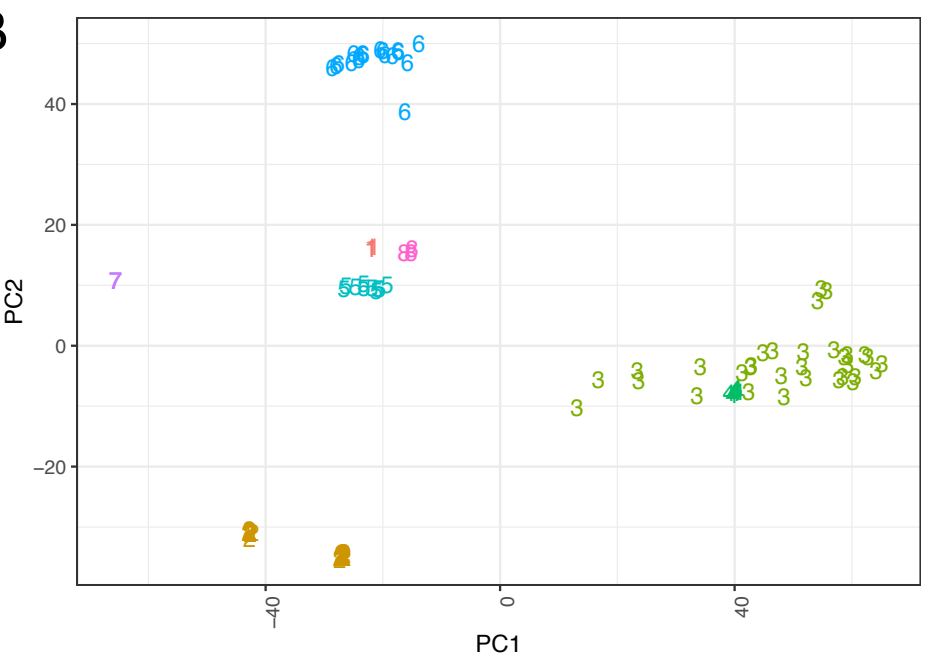

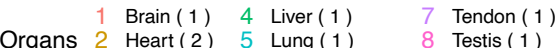

$\begin{array}{lllll}2 & \text { Heart (2) } & 5 & \text { Lung (1) } & 8 \text { Testis (1) } \\ 3 & \text { Kidney (1) } & 6 & \text { SpinalCord (1) } & \end{array}$

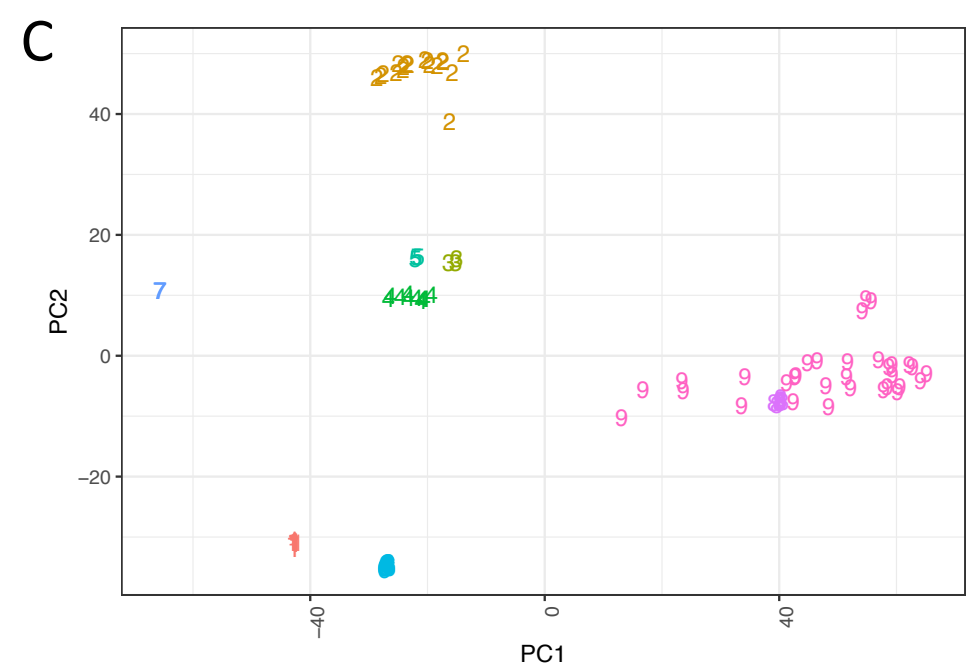

PXD001839 4 PXD006692 7 PXD015928 $\begin{array}{lllll}\text { PXD003375 } & 5 & \text { PXD012677 } & 8 & \text { PXD016793 } \\ \text { PXD004364 } & 6 & \text { PXD013543 } & 9 & \text { PXD016958 }\end{array}$ 
A Mouse

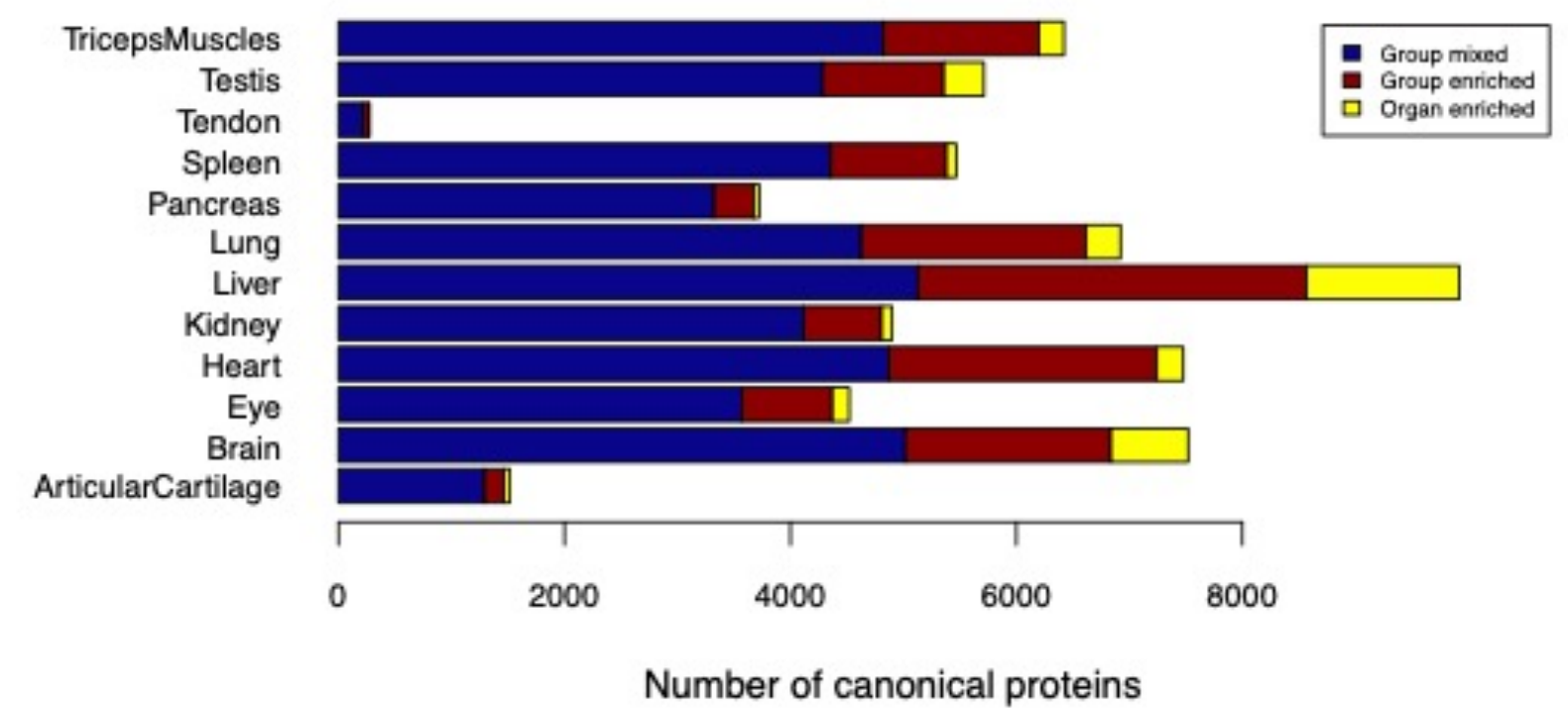

B

Rat

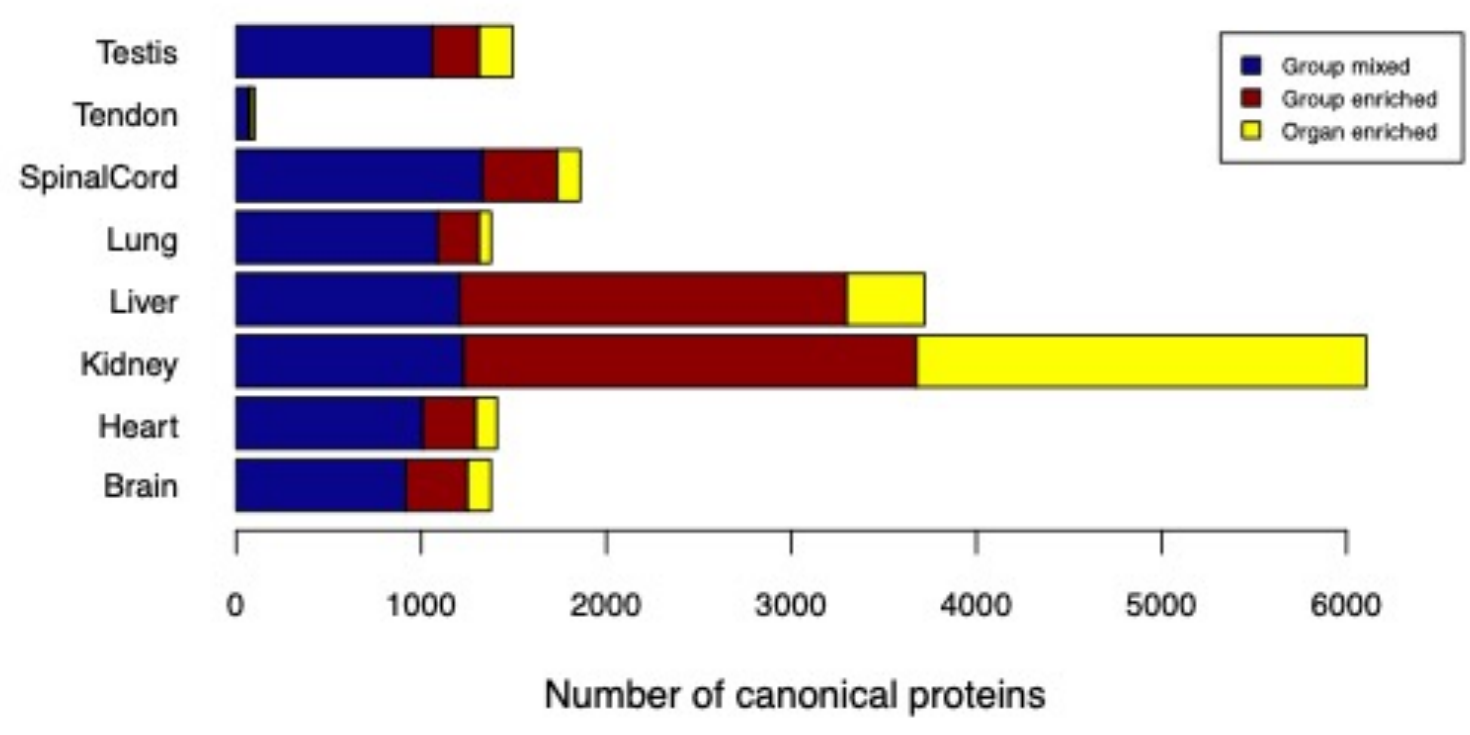




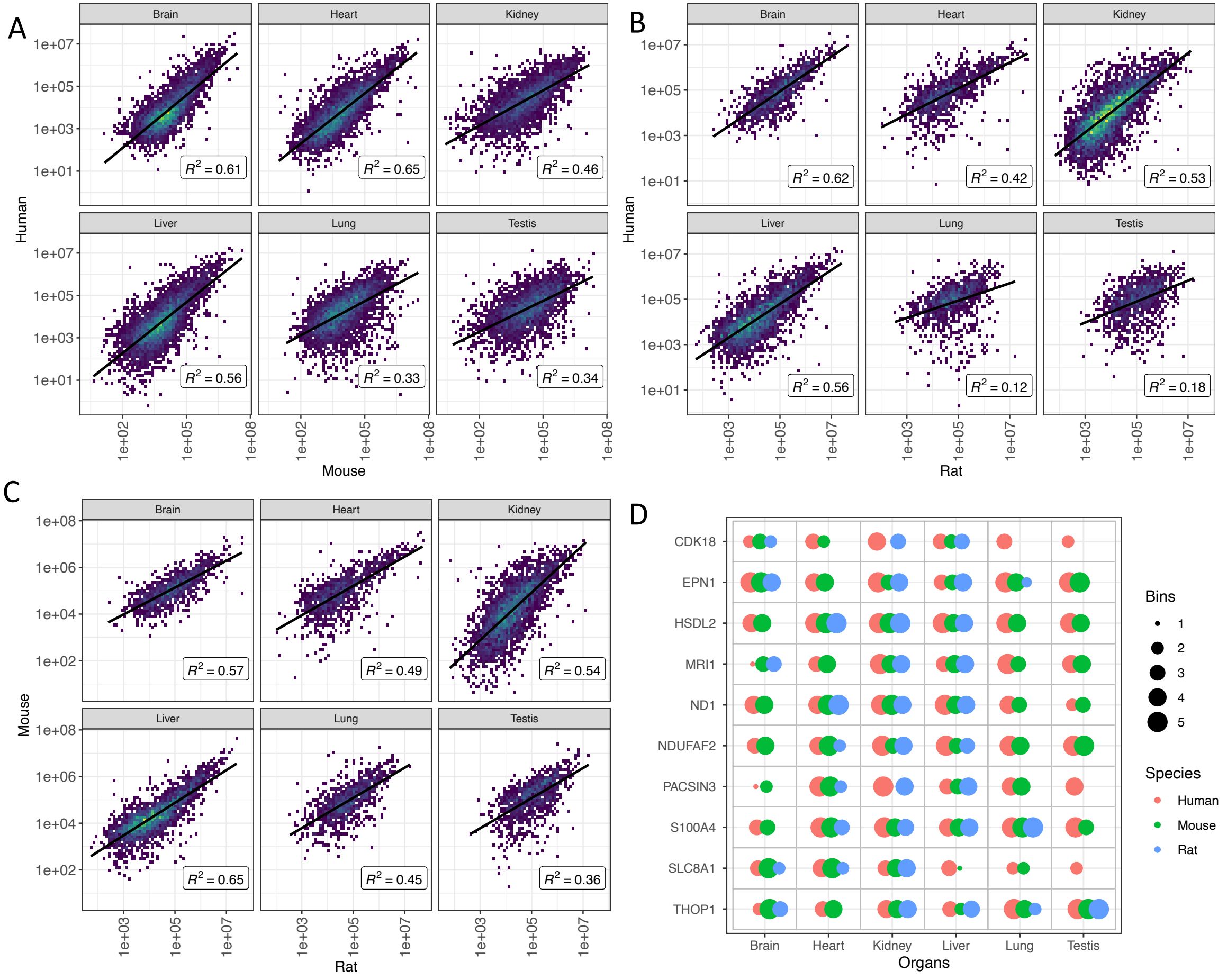




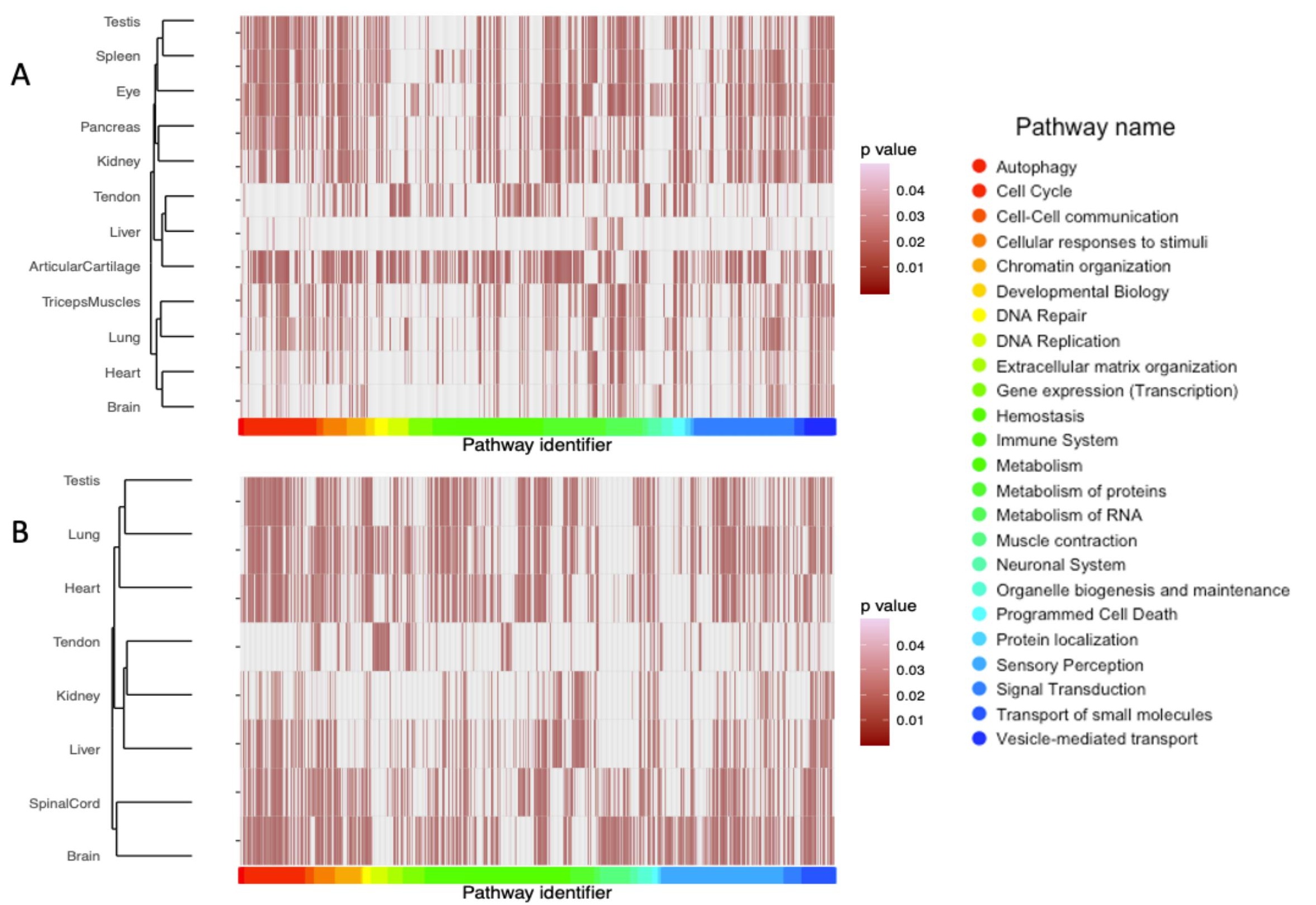

